\title{
Modulation of Amyloid States by Molecular Chaperones
}

\author{
Anne Wentink, Carmen Nussbaum-Krammer, and Bernd Bukau \\ Center for Molecular Biology of Heidelberg University (ZMBH) and German Cancer Research Center (DKFZ), \\ DKFZ-ZMBH Alliance, D-69120 Heidelberg, Germany \\ Correspondence: bukau@zmbh.uni-heidelberg.de
}

\begin{abstract}
Aberrant protein aggregation is a defining feature of most neurodegenerative diseases. During pathological aggregation, key proteins transition from their native state to alternative conformations, which are prone to oligomerize into highly ordered fibrillar states. As part of the cellular quality control machinery, molecular chaperones can intervene at many stages of the aggregation process to inhibit or reverse aberrant protein aggregation or counteract the toxicity associated with amyloid species. Although the action of chaperones is considered cytoprotective, essential housekeeping functions can be hijacked for the propagation and spreading of protein aggregates, suggesting the cellular protein quality control system constitutes a double-edged sword in neurodegeneration. Here, we discuss the various mechanisms used by chaperones to influence protein aggregation into amyloid fibrils to understand how the interplay of these activities produces specific cellular outcomes and to define mechanisms that may be targeted by pharmacological agents for the treatment of neurodegenerative conditions.
\end{abstract}

$\mathrm{T}_{\mathrm{i}}^{\mathrm{h}}$ he accumulation of protein aggregate deposits in the brain is a hallmark of most neurodegenerative conditions including Alzheimer's (AD), Parkinson's (PD), and Huntington's disease (HD) and amyotrophic lateral sclerosis (ALS) (Chiti and Dobson 2017). Although many neurodegenerative conditions arise sporadically, hereditary cases link increased concentrations or aggregation propensity of signature proteins to disease severity and early onset, suggesting a causal link between protein aggregation and disease phenotypes (Soto 2003).

Protein aggregates typically arise from the failure of the cellular protein quality control (PQC) machinery to refold or degrade mis- folded species in a timely manner (Tyedmers et al. 2010; Labbadia and Morimoto 2015). During aging, the capacity of the PQC network is decreased and becomes less responsive to protein misfolding stress signals, while damaged protein species accumulate (Blake et al. 1991; Ben-Zvi et al. 2009). The age-related decline of the PQC machinery has therefore been proposed to be a contributing factor to the late onset of protein aggregation in neurodegeneration (Labbadia and Morimoto 2015). The flip side to this hypothesis is that in early life, efficient PQC systems are in place to delay the onset of protein aggregation and, consequently, neurodegeneration. The effect of aging on protein ho-

Editors: Richard I. Morimoto, F. Ulrich Hartl, and Jeffery W. Kelly

Additional Perspectives on Protein Homeostasis available at www.cshperspectives.org

Copyright (C) 2019 Cold Spring Harbor Laboratory Press; all rights reserved; doi: 10.1101/cshperspect.a033969

Cite this article as Cold Spring Harb Perspect Biol 2019;11:a033969 
A. Wentink et al.

meostasis is further explored in Hartl (2018). Molecular chaperones play central roles in maintaining protein homeostasis in the cell as modulators of protein conformational states (Bukau et al. 2006; Kampinga and Craig 2010; Saibil 2013; Balchin et al. 2016). Chaperone action is therefore a key regulator in the pathological transition from the native protein conformation into the amyloid fibril (Hipp et al. 2014; Kampinga and Bergink 2016).

In this review, we discuss the various strategies used by chaperones to interfere with protein aggregation into amyloid fibrils and how their action may affect the progression of disease phenotypes. We illustrate molecular mechanisms of amyloid handling by the human chaperone machinery with specific case studies to provide an overview of the various ways in which protein aggregates can be targeted for therapeutic intervention in the context of neurodegenerative diseases.

\section{PROTEIN AGGREGATION IN NEURODEGENERATION}

Protein aggregates associated with neurodegeneration are typically characterized by a highly ordered, $\beta$-sheet-rich structure, termed amyloid (Chiti and Dobson 2017; Eisenberg and Sawaya 2017) (for additional details on the link between the amyloid state and human disease, see Dobson 2018). In vitro, the molecular mechanism of protein aggregation into amyloid fibrils has been described as a multistep pathway (Morris et al. 2009; Eichner and Radford 2011; Knowles et al. 2014) initiated by the stochastic or stress-induced conversion of a native protein into a misor unfolded and aggregation-prone state (Chen et al. 2002). The accumulation, subsequent oligomerization, and conformational rearrangement (Cremades et al. 2012; Neudecker et al. 2012) of such species leads to the formation of aggregation nuclei or "seeds" that act as templates of the amyloid conformation (Serio et al. 2000; Tanaka et al. 2006). The rapid templated incorporation of native monomers dramatically accelerates fibril growth. Fragmentation (Knowles et al. 2009) and secondary nucleation (Cohen et al. 2013), in which the surface of existing fibrils facilitates the formation of additional fibrillar seeds, exacerbate the phenotype rapidly by multiplying the number of ends from which aggregates can grow. Although the amyloid structure is energetically highly favorable (Baldwin et al. 2011), amyloid fibrils are not static entities but exist in equilibrium with monomer and oligomeric species (Fig. 1) (Carulla et al. 2005).

In vivo, interaction with cellular factors, molecular crowding, as well as posttranslational modifications and enzymatic processing all influence the aggregation behavior of amyloidogenic proteins and peptides (Oueslati et al. 2010; Stroo et al. 2017). Off-pathway oligomers and disordered aggregates are likely to coexist with the highly ordered amyloid conformation, each constituting their own challenge to the cellular PQC machinery (Lashuel et al. 2013; Kampinga and Bergink 2016).

The self-templating properties of the amyloid conformation are central to the prion hypothesis, which states that prions, the infectious particles causing a number of fatal transmissible neurodegenerative diseases, solely consist of an alternative $\beta$-sheet-rich, self-propagating amyloid conformation $\left(\mathrm{PrP}^{\mathrm{Sc}}\right)$ of the $\alpha$-helix-rich cellular prion protein $\operatorname{PrP}^{\mathrm{C}}$ (Prusiner 1998). The characteristic feature of the amyloid fold provides an explanation of how a single protein conformation can propagate without the transmission of genetic information. On infection, prions replicate not only at the molecular level, but also at the cellular level. This involves intercellular transmission of fibrillar seeds and the subsequent initiation and propagation of the amyloid conformation in naïve cells (Prusiner 1998). Although this phenomenon is a defining feature of infectious prion diseases, there is currently no epidemiological evidence that other prevalent human neurodegenerative diseases are contagious. However, a similar "prion-like" propagation has been described for other amyloid-forming proteins, including $\mathrm{AD}$-associated amyloid $\beta(\mathrm{A} \beta)$ and tau and $\mathrm{PD}$-associated $\alpha$-synuclein ( $\alpha$ syn), with aggregation initially developing in particular brain regions and subsequently spreading toward more distal interconnected regions in a stereotypic manner as 
Amyloid States Modulation by Molecular Chaperones
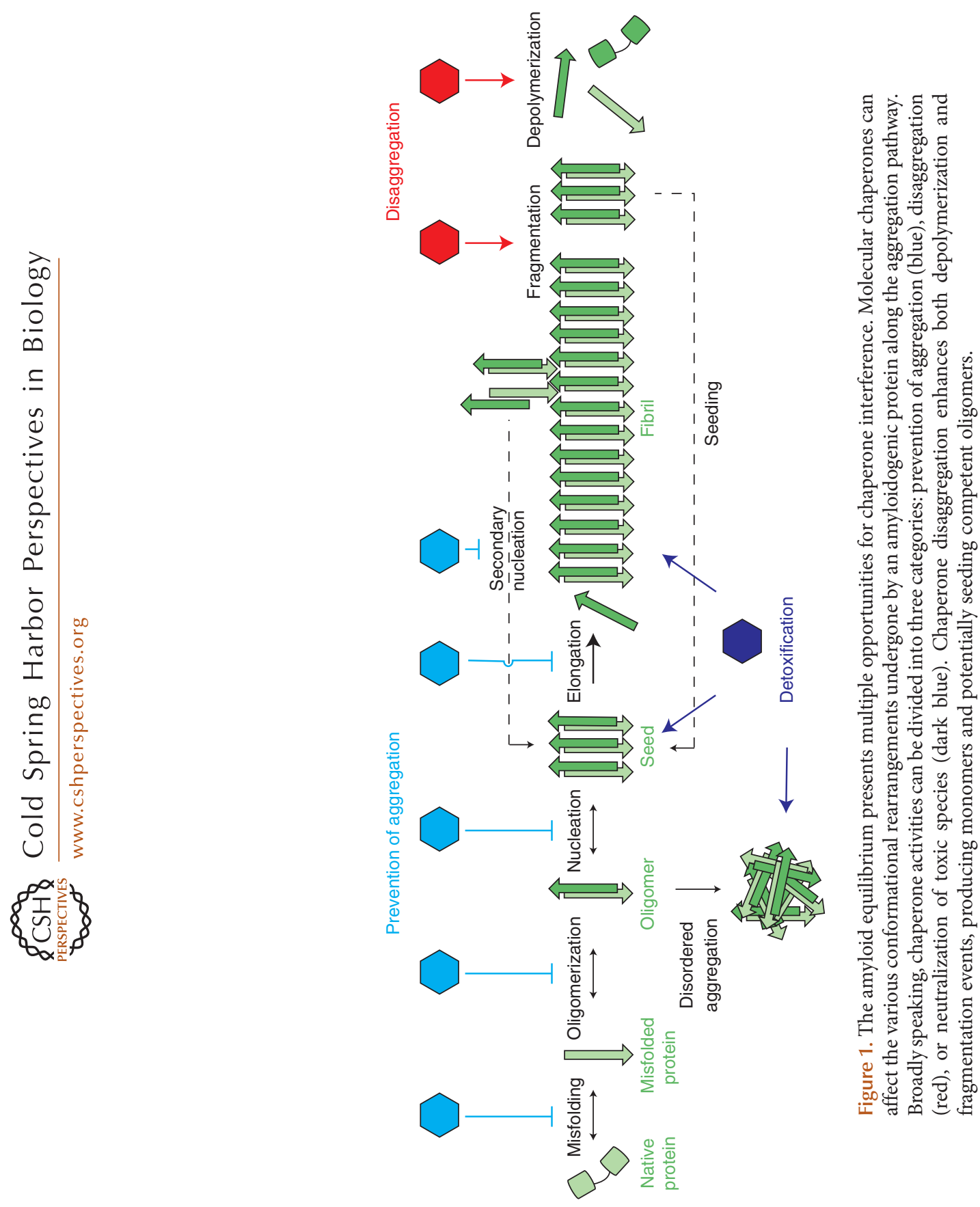
A. Wentink et al.

disease progresses (Brundin et al. 2010; Goedert et al. 2010). Hence, given the similarities in aggregate assembly, growth, and spreading, it is not surprising that many amyloidogenic proteins associated with neurodegenerative diseases are now considered to be prion-like.

A complex relationship exists between the various states of the amyloid equilibrium and cellular toxicity, with both on- and off-pathway oligomers as well as fibrillar species assigned to pathogenicity (Cohen and Dillin 2008; Sun et al. 2015; Tipping et al. 2015; Ries and NussbaumKrammer 2016). Moreover, as discussed in Eisenberg (2018) and Otzen and Riek (2018), not all amyloid-forming proteins are linked to disease. Diverging observations may be explained by inherent differences between various amyloidogenic proteins (Chiti and Dobson 2017), conformational differences in the resultant structures of their aggregation (Gath et al. 2014; Melki 2018), as well as the properties of flexible regions accessible for interaction with other cellular factors (Olzscha et al. 2011; Kim et al. 2016). For example, the amyloid structures of $\mathrm{A} \beta$ peptides integrate the entire amino acid sequence into their $\beta$-sheet folds (Luhrs et al. 2005; Paravastu et al. 2008; Gremer et al. 2017). Larger amyloidogenic proteins such as tau and asyn only partially bury their polypeptide sequence in the final amyloid core, exposing "fuzzy" coats of disordered overhang sequences (Vilar et al. 2008; Tuttle et al. 2016; Fitzpatrick et al. 2017; Guerrero-Ferreira et al. 2018). Smaller fibrillar and less-ordered oligomeric species, formed along the aggregation pathway, display proportionally larger hydrophobic surfaces that may make aberrant interactions with other cellular factors (Olzscha et al. 2011; Kim et al. 2016), sequester PQC machinery (Park et al. 2013; Yu et al. 2014; Guo et al. 2018), or disrupt cellular membranes (Quist et al. 2005; Campioni et al. 2010). The different properties of the oligomeric states that accumulate during protein aggregation provide multiple opportunities for the interaction with PQC components. Such oligomers are thought to be the dominant cytotoxic species, whereas larger amyloid aggregates are mainly regarded as inert and relatively cytoprotective because their size and highly ordered packing minimizes interactions with the cellular environment.

\section{MOLECULAR CHAPERONES AND PROTEIN QUALITY CONTROL}

In response to the threat of protein conformational instability, cells have evolved elaborate networks of chaperone proteins responsible for the folding, subcellular targeting, sequestration, disaggregation, and degradation of aggregationprone, unfolded, and misfolded protein species (Bukau et al. 2006; Kampinga and Craig 2010; Saibil 2013; Balchin et al. 2016). The expression of chaperones is up-regulated in a cell compartment-specific manner in response to protein misfolding stresses such as heat shock, oxidative stress, nutrient starvation, or genomic instability, to compensate for compromised protein homeostasis. The mechanisms of stress-induced up-regulation of chaperone expression and the complex coordination of this response across tissues in multicellular organisms are discussed in more detail in Joutsen and Sistonen (2018) and Morimoto (2018). Failure to elicit the cytosolic/nuclear heat shock response results in large-scale protein aggregation and possibly cell death. It is therefore noteworthy that some aggregation events associated with neurodegeneration, such as that of the polyglutamine ( polyQ) expanded Huntingtin protein $(\mathrm{Htt})$ in $\mathrm{HD}$, suppress this cellular response (Chafekar and Duennwald 2012), leading to further exacerbation of the already impaired proteostasis. Nevertheless, genetic or chemical activation of the heat shock response reduces aggregation in cell and animal models of PD and AD (Paris et al. 2010; Pierce et al. 2013). Moreover, the neuronal toxicity of aggregating $\alpha$ syn, tau, and $\mathrm{Htt}$ was reduced in animal model of neurodegeneration on Hsfl overexpression or local administration (Hay et al. 2004; Fujikake et al. 2008; Liangliang et al. 2010; Jiang et al. 2013).

The central cytosolic members of the chaperone network are the ATP-independent small heat shock proteins (sHSPs) and several ATPdependent chaperone families: Hsp70s with their cochaperones, in particular J-domain proteins (Hsp40s) and nucleotide exchange factors 
(NEFs) such as Hsp110, Hsp90 and its cochaperones, and the chaperonin TriC/CCT (Bukau et al. 2006; Kampinga and Craig 2010; Hartl and Bracher 2011; Li et al. 2012). These chaperone systems differ fundamentally in their modes of substrate binding, the conformational states of the substrates they recognize, and the changes they impose on their substrates. Figure 2 provides an overview of the key members of this chaperone network, their domain organization, and their substrate interaction modes. For further details, Biebl and Buchner (2018) and Janowska et al. (2018) elaborate on the complex functional regulation of Hsp90 and sHsps, respectively.

Amyloid-type aggregates present unique challenges for the cellular PQC machinery. In particular, the constituent proteins of amyloids do not display the typical characteristic of a chaperone substrate, that is, high exposed hydrophobicity, but instead present highly repetitive sequence and structural motifs resulting from the ordered stacking of monomers in the amyloid fibril. The cellular chaperone machinery, therefore, has to rely on unconventional and sometimes specialized molecular mechanisms to counteract protein aggregation in the context of neurodegeneration.

Chaperones appear to differ strongly in their effect on the various amyloidogenic proteins, highlighting both the strong similarities but also differences between the aggregation events underlying associated neurodegenerative conditions (Kakkar et al. 2014). $\alpha$ syn and tau intracellular aggregation, signatures of $\mathrm{PD}$ and $\mathrm{AD}$, respectively, are both reduced on induction of the heat shock response in cell culture models (Kakkar et al. 2014). Although generalized ATP-dependent chaperones can act at all stages of polyQ aggregation, noncanonical Hsp70 cochaperones, as well as sHSPs are more effective at preventing polyQ protein aggregation or counteracting disease phenotypes (Kakkar et al. 2014). A $\beta$ aggregation was shown to be strongly affected by a range of sHSPs in vitro; however, the physiological relevance of these observations is unknown because of the extracellular localization of $A \beta$ aggregates. Known in vitro chaperone interactions with amyloidogenic proteins are summarized in Table 1.
A pattern begins to emerge where peptide amyloids including $A \beta$ and unflanked polyQ stretches do not interact with the canonical Hsp70 chaperone machinery (Kakkar et al. 2014). sHSPs and specialized J domain chaperones interact predominantly with oligomeric states of these species to prevent further aggregation and/or suppress cytotoxicity. In contrast, relatively larger amyloidogenic proteins such as osyn, tau, and as notable exception Htt Exon1 that contain flexible flanking sequences in addition to the amyloid forming polyQ region, do interact with canonical Hsp70 cochaperones, including in their monomeric state, suggesting that it is not their amyloid-forming sequences but rather neighboring regions that allow binding of these chaperones (Monsellier et al. 2015).

\section{PREVENTION OF AGGREGATION BY MOLECULAR CHAPERONES}

As first line of defense against the formation of amyloid fibrils, the cellular PQC machinery employs various molecular strategies to prevent the (further) aggregation of the native protein pool. Classical chaperone folding and refolding activities rescue destabilized or misfolded protein species back to their native state. Transient interactions with misfolded proteins or small oligomers prevent their coalescence into seeding competent nuclei, while reducing accessibility to fibril ends prevents the further conversion of the native protein into amyloid fibrils. Finally, the decoration by chaperones along the fibrillar axis may interfere with the process of secondary nucleation, which can be a dominant driving force in accelerating protein aggregation under conditions where fibril fragmentation is limited (Fig. 1) (Cohen et al. 2013).

Chaperone "profolding" activities concern only the $\sim 35 \%$ subset of amyloidogenic proteins that attain a stable tertiary structure when folded to their native state (Chiti and Dobson 2017). Examples are the secreted immunoglobin light chain (Ig LC) and transthyretin (TTR) proteins that require the endoplasmic reticulum (ER) resident Hsp70 chaperone, HSPA5 (BIP), for folding into the IgG quaternary-structure and native tetramer, respectively (Blancas-Mejía 


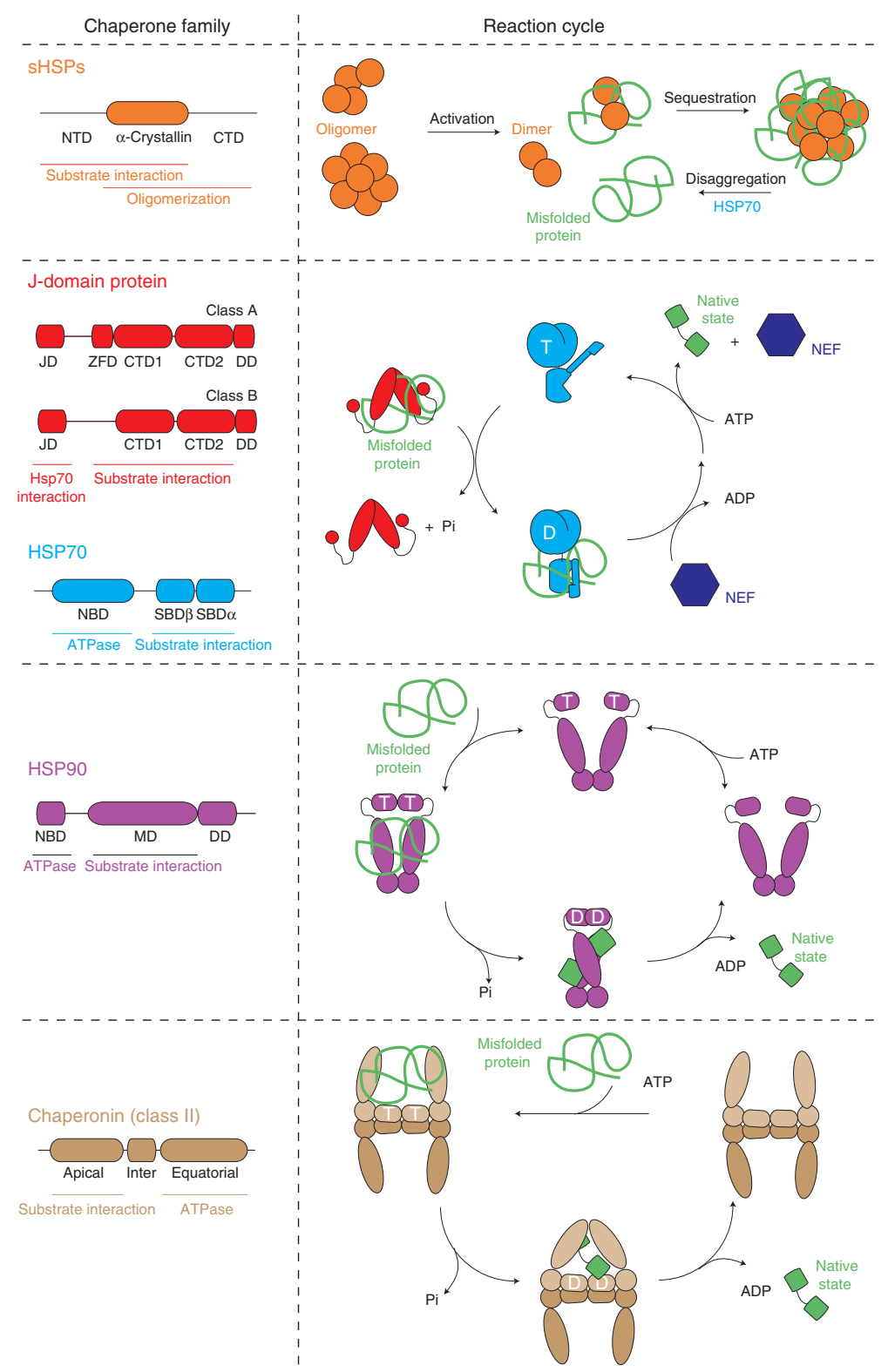

Figure 2. The cytosolic chaperone network. Chaperones in the human cytosol collaborate to identify, sequester, and refold misfolded proteins back to their native state. Molecular chaperones recognize similar hydrophobic motifs in substrates that are typically buried but become accessible on misfolding. Despite their overlapping substrate pools, their domain organization and substrate-binding modes differ significantly. sHsps rely on a complex oligomerization equilibrium to regulate their chaperoning activity in response to misfolding stressors and to sequester misfolded proteins. The Hsp70 family chaperoning conformational cycle is regulated by J-domain proteins, which target substrates to Hsp70, and NEFs that promote substrate release. Although Jdomain proteins can act as chaperones independently from Hsp70, chaperoning activity by NEFs is limited to the Hsp110-type only. Additional cellular factors serve to bridge the Hsp70 machine to downstream chaperones: Hsp90 and/or the class II chaperonin TriC/CCT. The nature of collaboration between the ATP-independent sHSPs and the Hsp70 machinery remains unknown. Nucleotide states throughout the chaperone functional cycles are indicated with "D" or “T” for ADP- or ATP-bound, respectively. CTD, carboxy-terminal domain; DD, dimerization domain; inter, intermediate domain; JD, J domain; MD, middle domain; NBD, nucleotide-binding domain; NTD, amino-terminal domain; NEF, nucleotide exchange factor; SBD, substrate-binding domain; ZFD, zinc finger domain. 
Amyloid States Modulation by Molecular Chaperones

Table 1. Chaperones described to modulate amyloid aggregation in vitro

\begin{tabular}{|c|c|c|c|c|c|}
\hline $\begin{array}{l}\text { Chaperone } \\
\text { family }\end{array}$ & Member & $\begin{array}{l}\text { Substrate } \\
\text { protein }\end{array}$ & $\begin{array}{l}\text { Activity } \\
\text { described }\end{array}$ & $\begin{array}{l}\text { Interacting } \\
\text { species }\end{array}$ & References \\
\hline \multirow[t]{5}{*}{$\begin{array}{l}\text { Small heat shock } \\
\text { proteins } \\
\text { (sHSPs) }\end{array}$} & HSPB1 (hsp27) & $\begin{array}{l}\alpha \text { syn } \\
\mathrm{A} \beta_{40 / 42} \\
\text { tau } \\
\mathrm{Htt}\end{array}$ & $\begin{array}{l}\text { Prevention of } \\
\text { aggregation } \\
\text { Neutralization }\end{array}$ & $\begin{array}{l}\text { Oligomer } \\
\text { Fibrils }\end{array}$ & $\begin{array}{l}\text { Wilhelmus et al. 2006a; } \\
\text { Ojha et al. 2011; } \\
\text { Baughman et al. 2018; } \\
\text { Cox et al. } 2018\end{array}$ \\
\hline & HSPB $2 / 3$ & $\begin{array}{l}\text { asyn } \\
\text { insulin }\end{array}$ & $\begin{array}{l}\text { Prevention of } \\
\text { aggregation }\end{array}$ & & $\begin{array}{l}\text { Bruinsma et al. 2011; } \\
\text { Prabhu et al. } 2012\end{array}$ \\
\hline & $\begin{array}{l}\text { HSPB5 } \\
\text { ( } \alpha B \text {-crystallin) }\end{array}$ & $\begin{array}{l}\alpha \text { syn } \\
\mathrm{A} \beta_{40 / 42} \\
\text { tau } \\
\beta_{2}-\mathrm{M}\end{array}$ & $\begin{array}{l}\text { Prevention of } \\
\text { aggregation } \\
\text { Neutralization } \\
\text { Disaggregation }\end{array}$ & $\begin{array}{l}\text { Monomer } \\
\text { Oligomer } \\
\text { Fibril }\end{array}$ & $\begin{array}{l}\text { Bruinsma et al. 2011; } \\
\text { Duennwald et al. 2012; } \\
\text { Mannini et al. 2012; } \\
\text { Cox et al. } 2016\end{array}$ \\
\hline & HSPB6 & $\begin{array}{l}\mathrm{A} \beta_{40 / 42} \\
\alpha \text { syn }\end{array}$ & $\begin{array}{l}\text { Prevention of } \\
\text { aggregation }\end{array}$ & Monomer & $\begin{array}{l}\text { Lee et al. 2005; } \\
\text { Wilhelmus et al. 2006a; } \\
\text { Bruinsma et al. } 2011\end{array}$ \\
\hline & HSPB8 & $\begin{array}{l}\mathrm{A} \beta_{40} \\
\text { polyQ } \\
\alpha \text { syn }\end{array}$ & $\begin{array}{l}\text { Prevention of } \\
\text { aggregation }\end{array}$ & Monomer & $\begin{array}{l}\text { Wilhelmus et al. 2006b; } \\
\text { Bruinsma et al. } 2011\end{array}$ \\
\hline \multirow{6}{*}{$\begin{array}{l}\text { J-domain } \\
\text { proteins } \\
(\text { Hsp40) }\end{array}$} & DNAJA1 & tau & $\begin{array}{l}\text { Prevention of } \\
\text { aggregation }\end{array}$ & Monomer & Mok et al. 2018 \\
\hline & DNAJA2 & tau & $\begin{array}{l}\text { Prevention of } \\
\text { aggregation }\end{array}$ & Monomer & Mok et al. 2018 \\
\hline & DNAJB1 & $\begin{array}{l}\text { asyn } \\
\text { polyQ } \\
\text { IAPP }\end{array}$ & $\begin{array}{l}\text { Prevention of } \\
\quad \text { aggregation } \\
\text { Disaggregation }\end{array}$ & Fibril & $\begin{array}{l}\text { Pemberton et al. 2011; } \\
\text { Duennwald et al. 2012; } \\
\text { Gao et al. } 2015\end{array}$ \\
\hline & DNAJB2 & polyQ & $\begin{array}{l}\text { Prevention of } \\
\text { aggregation }\end{array}$ & Oligomer & Labbadia et al. 2012 \\
\hline & DNAJB6 & $\begin{array}{l}\mathrm{A} \beta \\
\alpha \text { syn } \\
\text { polyQ }\end{array}$ & $\begin{array}{l}\text { Prevention of } \\
\text { aggregation }\end{array}$ & Oligomer & $\begin{array}{l}\text { Månsson et al. 2014a,b; } \\
\text { Aprile et al. } 2017\end{array}$ \\
\hline & DNAJB8 & $\begin{array}{l}\text { asyn } \\
\text { polyQ }\end{array}$ & $\begin{array}{l}\text { Prevention of } \\
\text { aggregation }\end{array}$ & Oligomer & $\begin{array}{l}\text { Månsson et al. 2014b; } \\
\text { Aprile et al. } 2017\end{array}$ \\
\hline \multirow[t]{3}{*}{ Hsp70 } & $\begin{array}{l}\text { HSPA1A } \\
(\text { Hsp70) }\end{array}$ & $\begin{array}{l}\mathrm{A} \beta \\
\alpha \text { syn } \\
\text { IAPP } \\
\text { IgG } \\
\text { tau }\end{array}$ & $\begin{array}{l}\text { Prevention of } \\
\text { aggregation }\end{array}$ & $\begin{array}{l}\text { Monomer } \\
\text { Oligomer }\end{array}$ & $\begin{array}{l}\text { Wacker et al. 2004; } \\
\text { Dedmon et al. 2005; } \\
\text { Evans et al. 2006; } \\
\text { Chien et al. 2010; } \\
\text { Voss et al. 2012; } \\
\text { Rosas et al. } 2016\end{array}$ \\
\hline & $\begin{array}{l}\text { HSPA5 } \\
\text { (Bip) }\end{array}$ & $\begin{array}{l}\text { IAPP } \\
\text { IgG }\end{array}$ & $\begin{array}{l}\text { Prevention of } \\
\text { aggregation }\end{array}$ & & $\begin{array}{l}\text { Davis et al. 2000; } \\
\quad \text { Chien et al. } 2010\end{array}$ \\
\hline & $\begin{array}{l}\text { HSPA8 } \\
(\text { Hsc70) }\end{array}$ & $\begin{array}{l}\text { HttExl } \\
\alpha \text { syn } \\
\text { tau }\end{array}$ & $\begin{array}{l}\text { Prevention of } \\
\quad \text { aggregation } \\
\text { Disaggregation }\end{array}$ & $\begin{array}{l}\text { Monomer } \\
\text { Oligomer } \\
\text { Fibril }\end{array}$ & $\begin{array}{l}\text { Muchowski et al. 2000; } \\
\text { Pemberton et al. 2011; } \\
\text { Duennwald et al. 2012; } \\
\text { Gao et al. 2015; } \\
\text { Monsellier et al. 2015; } \\
\text { Mok et al. 2018; } \\
\text { Scior et al. 2018 }\end{array}$ \\
\hline
\end{tabular}


A. Wentink et al.

Table 1. Continued

\begin{tabular}{|c|c|c|c|c|c|}
\hline $\begin{array}{l}\text { Chaperone } \\
\text { family }\end{array}$ & Member & $\begin{array}{l}\text { Substrate } \\
\text { protein }\end{array}$ & $\begin{array}{l}\text { Activity } \\
\text { described }\end{array}$ & $\begin{array}{l}\text { Interacting } \\
\text { species }\end{array}$ & References \\
\hline NEFs & $\begin{array}{l}\text { HSPH2 } \\
\text { (Apg2) }\end{array}$ & $\begin{array}{l}\alpha \text { syn } \\
\text { HttEx1 }\end{array}$ & Disaggregation & Fibril & $\begin{array}{l}\text { Duennwald et al. 2012; } \\
\text { Gao et al. } 2015\end{array}$ \\
\hline Hsp90 & HSPC1 & $\begin{array}{l}\mathrm{A} \beta \\
\alpha \text { syn } \\
\text { tau }\end{array}$ & $\begin{array}{l}\text { Prevention of } \\
\text { aggregation }\end{array}$ & Oligomers & $\begin{array}{l}\text { Evans et al. 2006; } \\
\text { Falsone et al. 2009; } \\
\text { Daturpalli et al. 2013; } \\
\text { Schirmer et al. } 2016\end{array}$ \\
\hline \multirow[t]{2}{*}{ Chaperonin } & TriC/CCT & $\begin{array}{l}\text { asyn } \\
\text { polyQ }\end{array}$ & $\begin{array}{l}\text { Prevention of } \\
\text { aggregation } \\
\text { Neutralization }\end{array}$ & $\begin{array}{l}\text { Monomer } \\
\text { Oligomer } \\
\text { Fibril }\end{array}$ & $\begin{array}{l}\text { Behrends et al. 2006; } \\
\text { Tam et al. 2009; } \\
\text { Shahmoradian et al. 2013; } \\
\text { Sot et al. } 2017\end{array}$ \\
\hline & Hsp60 & tau & $\begin{array}{r}\text { Prevention of } \\
\text { aggregation }\end{array}$ & $\begin{array}{l}\text { Monomer } \\
\text { Oligomer }\end{array}$ & Mok et al. 2018 \\
\hline $\begin{array}{l}\text { Ribosome- } \\
\text { associated } \\
\text { chaperones }\end{array}$ & NAC & $\alpha$ syn & $\begin{array}{l}\text { Prevention of } \\
\text { aggregation }\end{array}$ & Monomer & Martin et al. 2018 \\
\hline \multirow[t]{3}{*}{$\begin{array}{l}\text { Brichos-domain } \\
\text { proteins }\end{array}$} & proSP-C & $\begin{array}{l}\mathrm{SP}-\mathrm{C} \\
\mathrm{A} \beta_{40 / 42}\end{array}$ & $\begin{array}{l}\text { Prevention of } \\
\text { aggregation }\end{array}$ & Fibril & Willander et al. 2012 \\
\hline & gastrokine1 & $\mathrm{A} \beta_{40}$ & $\begin{array}{l}\text { Prevention of } \\
\text { aggregation }\end{array}$ & Monomer & Altieri et al. 2014 \\
\hline & Bri2 & $\begin{array}{l}\mathrm{A} \beta_{40 / 42} \\
\text { IAPP }\end{array}$ & $\begin{array}{r}\text { Prevention of } \\
\text { aggregation }\end{array}$ & Fibril & $\begin{array}{l}\text { Willander et al. 2012; } \\
\text { Oskarsson et al. } 2018\end{array}$ \\
\hline \multirow[t]{3}{*}{$\begin{array}{l}\text { Extracellular } \\
\text { chaperones }\end{array}$} & $\begin{array}{l}\alpha_{2} \text {-macro- } \\
\text { globulin }\end{array}$ & $\begin{array}{l}\mathrm{A} \beta_{42} \\
\text { Calcitonin } \\
\text { HypF-N } \\
\text { Lysozyme }\end{array}$ & $\begin{array}{l}\text { Prevention of } \\
\text { aggregation } \\
\text { Neutralization }\end{array}$ & Oligomer & $\begin{array}{l}\text { Hughes et al. 1998; } \\
\text { Yerbury et al. 2009; } \\
\text { Mannini et al. } 2012\end{array}$ \\
\hline & Clusterin & $\begin{array}{l}\mathrm{A} \beta_{40 / 42} \\
\text { ApoCII } \\
\alpha \text { syn } \\
\text { Calcitonin } \\
\text { Lysozyme } \\
\text { tau } \\
\text { TDP43 } \\
\text { TTR }\end{array}$ & $\begin{array}{l}\text { Prevention of } \\
\text { aggregation } \\
\text { Neutralization }\end{array}$ & $\begin{array}{l}\text { Monomer } \\
\text { Oligomer }\end{array}$ & $\begin{array}{l}\text { Kumita et al. 2007; } \\
\text { Narayan et al. 2012; } \\
\text { Greene et al. 2015; } \\
\text { Mok et al. } 2018\end{array}$ \\
\hline & Haptoglobin & $\begin{array}{l}\mathrm{A} \beta_{42} \\
\text { Calcitonin } \\
\text { Lysozyme }\end{array}$ & $\begin{array}{l}\text { Prevention of } \\
\text { aggregation }\end{array}$ & Oligomer & Yerbury et al. 2009 \\
\hline \multirow[t]{3}{*}{ Other } & Prefoldin & $\begin{array}{l}\mathrm{A} \beta_{42} \\
\mathrm{Htt}\end{array}$ & $\begin{array}{l}\text { Prevention of } \\
\text { aggregation }\end{array}$ & Oligomer & $\begin{array}{l}\text { Sakono et al. 2008; } \\
\text { Tashiro et al. } 2013\end{array}$ \\
\hline & $7 \mathrm{~B} 2$ & $\begin{array}{l}\alpha \text { syn } \\
\mathrm{A} \beta_{40 / 42} \\
\text { IAPP }\end{array}$ & $\begin{array}{l}\text { Prevention of } \\
\text { aggregation }\end{array}$ & & $\begin{array}{l}\text { Helwig et al. 2013; } \\
\quad \text { Peinado et al. } 2013\end{array}$ \\
\hline & ApoE & $\mathrm{A} \beta_{40}$ & $\begin{array}{l}\text { Prevention of } \\
\text { aggregation }\end{array}$ & & Evans et al. 1995 \\
\hline
\end{tabular}


and Ramirez-Alvarado 2013). Although unassembled Ig LC and TTR monomers are typically retained in the ER, reduced proteostasis capacity leads to their aberrant secretion and subsequent extracellular aggregation into amyloid fibrils (Lee et al. 1999; Sorgjerd et al. 2006). Destabilization of their native folds by mutation or the absence of partner subunits promotes sustained HSPA5 (BIP) interaction (Melnick et al. 1994; Lee et al. 1999; Quintas et al. 2001; Sorgjerd et al. 2006). This more stringent quality control reduces the secretion of destabilized TTR and Ig LC and thus suppresses extracellular protein aggregation (Melnick et al. 1994; Davis et al. 2000). Conversely, chemical disruption of ER proteostasis, reducing chaperone availability, results in an accumulation of extracellular aggregates (Chen et al. 2016), demonstrating that indeed the preservation of native protein folds, in conjunction with the timely ER retention and degradation of nonnative folds by ER-associated degradation (ERAD) is an efficient mechanism to suppress amyloid formation (Fig. 1, "misfolding").

Chaperones can prevent aggregation of misfolded proteins that escape the PQC machinery, or of the predominant intrinsically disordered, low-complexity proteins associated with neurodegeneration, through interference with primary nucleation. Transient interactions with aggregation-prone regions in monomeric proteins or sequences in close proximity, can prevent their initial oligomerization into seeding competent aggregates. This strategy corresponds to the classical "holding" activity (Mattoo and Goloubinoff 2014) of sHSPs and canonical Jdomain proteins as well as the activity of other HSPs, including Hsp70 and Hsp110, where the binding to a substrate sequence sterically interferes with the aggregation process (Fig. 1, "oligomerization"). The native tau interactions with the Hsp70 and Hsp90 chaperone machinery illustrates this concept well. As an intrinsically disordered protein, tau does not rely on these chaperones for folding; however, its interaction with chaperones is essential to regulate tau microtubule association, phosphorylation status, and degradation (Jinwal et al. 2010; Thompson et al. 2012; Karagoz et al. 2014). Perturbations in these interactions result in the accumulation and aggregation of hyperphosphorylated tau (Jinwal et al. 2013; Wang et al. 2013; Young et al. 2018). Chaperone "holding" activities may also compete with the further elongation of preexisting fibrils, as discussed in further detail below.

Alternatively, primary nucleation can be suppressed through the stabilization of intermediate, non-seeding-competent oligomeric states before their conversion into aggregation "seeds." This particular mechanism appears to be used by the noncanonical J-domain proteins, DNAJB6, and DNAJB8. DNAJB6 effectively suppresses the aggregation of various members of the polyQ expanded protein family (Månsson et al. 2014b) as well as $A \beta_{42}$ (Månsson et al. 2014a) in vitro and in cell culture models on overexpression (Gillis et al. 2013), and improves cognitive function in a mouse model of HD (Kakkar et al. 2016). Kinetic analysis of the in vitro aggregation behavior of polyQ proteins and $A \beta$ in the presence of DNAJB6 revealed that the chaperone predominantly inhibits primary nucleation through interaction with small oligomers, rather than monomeric species (Månsson et al. 2014a; Arosio et al. 2016; Kakkar et al. 2016). DNAJB6/8 contain, in addition to classical structural features of the DNAJB class (Fig. 2; Kampinga and Craig 2010), a signature region rich in serine and threonine residues that is hypothesized to specifically interact with the $\beta$-hairpin hydrogen bonding network of polyQ-containing protein and possibly other amyloidogenic protein aggregates (Kakkar et al. 2016; Månsson et al. 2018; Soderberg et al. 2018). DNAJB6 forms higher oligomeric complexes and therefore presents multiple substrate interfaces (Soderberg et al. 2018), suggesting that its oligomeric status conveys the ability to specifically recognize amyloidogenic oligomers (Fig. 1, "nucleation").

Once nucleation occurs, aggregation "seeds" can rapidly elongate through the templated incorporation of monomers. Monomer sequestration by chaperones can compete with this process through the depletion of the available monomer pool (Wacker et al. 2004; Luheshi et al. 2010). Conversely, chaperones may act on the fibrillar state to sterically hinder further monomer incorporation. The sHSPs HSPB1 and 
A. Wentink et al.

HSPB5 have been described to act in this way, preventing the further elongation of $A \beta_{40 / 42}$ and $\alpha$ syn amyloid fibrils at substoichiometric chaperone concentrations (Waudby et al. 2010; Shammas et al. 2011). The $\beta$-sandwich folds of the $\alpha$-crystallin domains of HSPB1/5 (Fig. 2) are crucial for the interaction with amyloid fibrils. It is likely that the $\beta$-sheet of the sHSP dimerization interface in the $\alpha$-crystallin domain matches the hydrogen bonding register of preformed fibrils, effectively capping the fibrils (Mainz et al. 2015). A side effect of this interaction is that preformed fibrils are stabilized, as preintegrated monomers can no longer dissociate (Fig. 1, “elongation”) (Raman et al. 2005).

Finally, chaperones can suppress aggregation through the inhibition of secondary nucleation. Secondary nucleation events are aggregation events catalyzed by the surface of preformed fibrils, which rapidly creates new fibrillar seeds and thus increases protein aggregation rates. Chaperones that interact with the surface of amyloid fibrils can interfere with this phenomenon (Table 1). The best characterized example of a chaperone family that uses this mechanism is the BRICHOS domain-containing proteins. BRICHOS domains appear to have evolved to shield $\beta$-sheet-prone regions of their respective proproteins from aggregation (Mao et al. 2016), but additionally interfere in the oligomerization of other amyloidogenic proteins, in particular $\mathrm{A} \beta_{42}$ (Willander et al. 2012). In vitro, $A \beta_{42}$ aggregation is reduced predominantly through the inhibition of secondary nucleation (Cohen et al. 2015); BRICHOS domains thus do not prevent the initial formation of amyloid fibrils but suppress the amplification effects of new aggregation seeds. The underlying molecular interactions have thus far not been described. Overexpression of the Bri2 BRICHOS domain strongly inhibits $A \beta$ aggregation in a Drosophila model of $\mathrm{AD}$ (Fig. 1: "secondary nucleation") (Poska et al. 2016).

The development of detailed kinetic analyses of in vitro aggregation data has greatly contributed to our understanding of the chaperoning mechanisms that act to prevent the aggregation of amyloidogenic proteins and the oligomeric state that they act on (Arosio et al.
2016). The inherent promiscuity of chaperone interactions with their substrates means that chaperones often act on multiple conformational species that accumulate during aggregation and thus interfere with various microscopic processes simultaneously (Table 1). A case in point are the sHSPs that not only act to prevent elongation through interaction at fibril ends but also reduce secondary nucleation through similar interactions along the fibril axis. Moreover, their presence makes preformed fibrillar species more susceptible to disaggregation by the Hsp70 machinery (see section on Chaperone-Driven Disaggregation of Amyloid Species). Their interaction with oligomeric species stabilizes nonseeding-competent conformations, and a subset of sHSP may act to neutralize such oligomeric species through the regulated aggregation and sequestration into quality control compartments (see next section).

\section{NEUTRALIZATION/DETOXIFICATION OF PROTEIN AGGREGATES}

An additional consequence of the interaction of chaperones with oligomers and fibrils of amyloidogenic proteins is the detoxification of such species in the cell. A first approach to counteracting the toxicity of, in particular, smaller oligomeric states is reducing the total exposed hydrophobicity by increasing the size of aggregates. Indeed, formation of large intracellular inclusion bodies correlates with increased survival of neurons expressing mutant Htt (Arrasate et al. 2004).

Chaperones, including sHSP HSPB1 and extracellular chaperones clusterin, $\alpha_{2}$ macroglobulin, and haptaglobin (Ojha et al. 2011; Mannini et al. 2012), interact with protein oligomers in vitro to form higher-order complexes of amyloid-forming proteins, including $A \beta 42$, IAPP, and HypF-N. Such sequestration does not dramatically alter the structure of the aggregates (as judged by thioflavin $\mathrm{T}$ fluorescence and circular dichroism analysis) but strongly reduces their cellular toxicity (Ojha et al. 2011). Detoxification relies not only on the increased size of the aggregate, but also on the shielding action of chaperone binding, which prevents unspecific 
interactions with other cellular proteins (Beeg et al. 2016). Notably, the chaperonin TRiC/ CCT, which prevents the aggregation of $\mathrm{Htt}$ Exon1 through transient interactions with oligomeric and fibrillar species (Tam et al. 2006; Shahmoradian et al. 2013; Pavel et al. 2016), can additionally act to detoxify polyQ proteins by promoting the assembly of soluble, nontoxic oligomeric species that are larger in size $(\sim 500$ $\mathrm{kDa})$ than their toxic counterparts $(\sim 200 \mathrm{kDa})$ (Behrends et al. 2006).

A "sequestrase" activity of sHSPs, which mediates the formation of organized protein foci (Specht et al. 2011; Escusa-Toret et al. 2013; Miller et al. 2015), was shown to be essential for survival of yeast cells subjected to severe and repetitive protein misfolding stresses (EscusaToret et al. 2013; Ungelenk et al. 2016; Mogk et al. 2018). Although an analogous role for their sHSP repertoire has not yet been shown, mammalian cells respond similarly to the proteotoxic stress associated with proteasomal impairment, by sequestering misfolded proteins into large deposits termed aggresomes located near the centrosome (Johnston et al. 1998). Polyubiquitinated substrates are targeted to this site by Hsp70 and its NEF cochaperone BAG3 as well as the adaptor proteins 14-3-3 or HDAC6, which couple the aggregate cargo to dynein for trafficking (Gamerdinger et al. 2011; Xu et al. 2013). The aggresome is considered a storage site for aggregates facilitating clearance by autophagy (Kopito 2000). It should be noted that aggresome structures have mainly been described in cell culture models and do not necessarily correspond to inclusion bodies associated with neurodegenerative diseases. However, they clearly represent a cytoprotective stress response and their studies shed light on how cells manage acute protein misfolding stress. Finally, in Caenorhabditis elegans, long-lived daf-2 mutants show increased accumulation of large insoluble aggregates as compared with wild type (WT), suggesting that intracellular sequestration of aggregation-prone proteins is beneficial to organismal longevity (Walther et al. 2015). Nevertheless, the biological relevance of (sHSP-mediated) sequestration of aggregates formed by amyloidogenic proteins in mammalian cells remains to be established.
Detoxification of amyloids by chaperones can also follow an indirect mechanism, in which rather than acting on the aggregate itself, chaperones such as the Hsp70 system extract coaggregated protein species from deposits. This may counteract cellular toxicity induced by the sequestration of essential proteins (e.g., transcription factors) (Olzscha et al. 2011). Conversely, such extraction activity may sequester essential PQC components toward amyloid-induced deposits and away from essential housekeeping functions (Hinault et al. 2010). That chaperone sequestration by aggregates can perturb housekeeping functions was shown for the role of the constitutive Hsp70, HSPA8 (Hsc70), in endocytosis on protein aggregation (Yu et al. 2014). In yeast, the aggregation of overexpressed polyQ proteins results in the sequestration of Jdomain protein DNAJB1 homolog Sis1, blocking a PQC pathway that shuttles target proteins for proteasomal degradation in the nucleus (Park et al. 2013). Moreover, oligomeric species of amyloidogenic proteins can block proteasomal activity through direct ubiquitin-independent interaction with the 20S subunit, reducing overall cellular degradative capacity (Thibaudeau et al. 2018). Beyond its burden on the PQC network as a substrate, oligomer and amyloid species formed by amyloidogenic proteins can thus interfere with standard housekeeping functions of the PQC in unexpected ways.

\section{CHAPERONE-DRIVEN DISAGGREGATION OF AMYLOID SPECIES}

Once amyloid fibrils are formed, molecular chaperones may act to reverse protein aggregation. A priori, amyloid disaggregation by molecular chaperones can occur through either passive or active processes. In the passive process, monomers that spontaneously dissociate from the fibrils are captured by chaperones, thus shifting the amyloid equilibrium to a soluble state. In the active process, chaperones act on the fibrillar state to accelerate depolymerization of monomers or destabilize the fibril core to such extent that fibrils fragment.

To date, the best characterized and apparent most versatile disaggregase activity in the hu- 
A. Wentink et al.

man cell is provided by the Hsp70 machinery (Fig. 3). The Hsp70 chaperone family acts through the regulated conformational cycling of Hsp70 between an open ATP-bound state and a closed, high-substrate affinity ADP-bound state. Substrate binding and trapping through ATP hydrolysis is assisted by J-domain proteins, while ADP release, and timed substrate release on ATP rebinding are driven by NEFs (Fig. 2). Hsp70s recognize a degenerate motif of about five residues enriched in hydrophobic amino acids, flanked by positively charged amino acids (statistically occurring every 30-40 residues in protein sequences) (Rudiger et al. 1997). Surface exposure of this peptide motif in protein substrates allows for Hsp70 binding to a wide range of conformers from unfolded nascent peptides and protein aggregates to near native conformations. Importantly, the J-domain proteins belonging to the class $\mathrm{A}$ and class B families have substrate-binding activities themselves (Rudiger et al. 2001). The engagement of substrates by J-domain proteins, at binding sites in proper distance to Hsp70-binding sites, precedes or coincides with the association of Hsp70 partner chaperones. J-domain proteins are therefore substrate-targeting factors for Hsp70s.
Because of their broad substrate specificity, J-domain proteins and Hsp70s act at multiple levels of the amyloid aggregation equilibrium in vitro, including preventing the aggregation of osyn, $A \beta$, tau, as well as polyQ-containing aggregates through transient interaction with monomers and oligomers, removal of coaggregated protein species, and solubilization of preformed amyloid fibrils (Table 1).

Efficient disaggregation of asyn (Duennwald et al. 2012; Gao et al. 2015) and Htt Exon1 (Scior et al. 2018) amyloid fibrils by human HSPA8 (Hsc70), relies on the canonical class B J-domain protein DNAJB1 and Hsp110-type NEFs (Fig. 2). Other J-domain proteins such as DNAJA1 and DNAJA2, implicated in the dissolution of disordered protein aggregates (Nillegoda et al. 2015), cannot substitute in vitro, suggesting a specific function for DNAJB1 in the recognition of amyloid substrates. In C. elegans, however, J-domain proteins of both class A and class B appear to act synergistically to reduce polyQ aggregate load (Kirstein et al. 2017). To what extent this observation can be attributed to differential roles of the J-domain protein classes in prevention of aggregation versus disaggregation remains to be characterized in further detail. A recent study on chaperone modu-

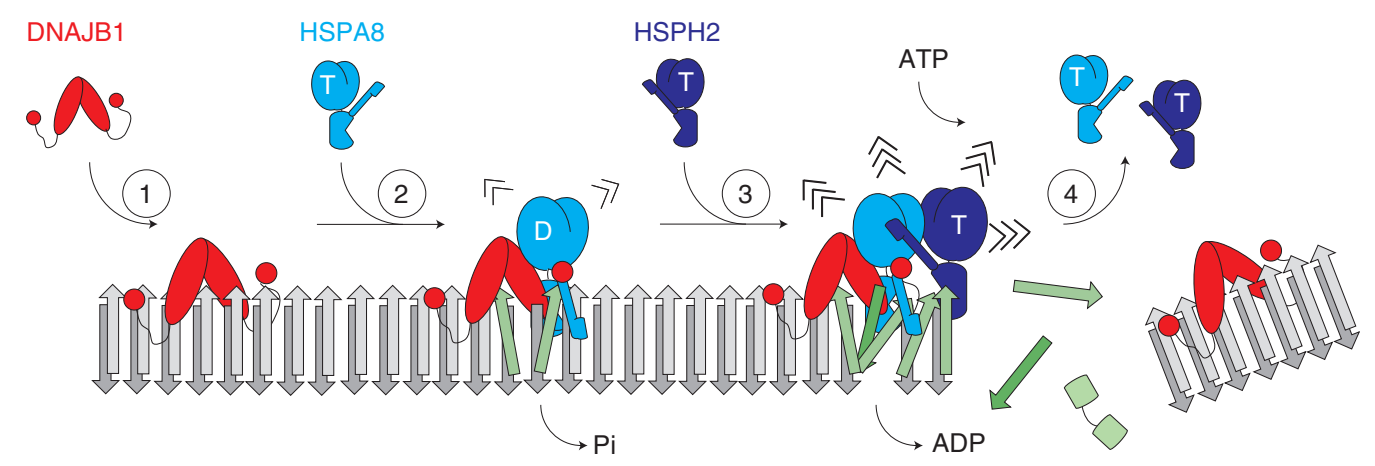

Figure 3. Amyloid disaggregation by the human Hsp70 machinery. DNAJB1 identifies substrates as Hsp70 machinery targets based on sequence and structural features (1). DNAJB1 substrate engagement allows the recruitment of HSPA8-ATP to the fibril surface (2). Catalyzed ATP hydrolysis converts the HSPA8/fibril complex to a long-lived, high-affinity state (3). Recruitment of the Hsp110-type nucleotide exchange factor HSPH2 (Apg2) displaces ADP and allows ATP rebinding to HSPA8, resulting in substrate release (4). Reinitiated recruitment of HSPA8 by DNAJB1 to remaining fibrillar fragments allows for complete solubilization of amyloid fibrils. The pulling energies required for amyloid disaggregation are putatively generated during phase 2 and 3 as indicated by the ">" symbols. 
lators of tau aggregation (Mok et al. 2018) corroborates the idea that J-domain proteins of class A may preferentially act to prevent amyloid formation, acting predominantly on small aggregate species or monomers, while members of class B target fibrils and large oligomers to disaggregation (Nillegoda et al. 2015).

The disaggregation activity of Hsp70 further relies on the NEF activity of Hsp110-type cochaperones. It is worth noting that other NEFs (Fig. 2) cannot complement well in disaggregation activity, suggesting that a particular feature of the Hsp110 family is essential to tuning the Hsp70 machinery for disaggregation. One such defining feature may be the unique ability of Hsp110s to bind to substrates themselves (Xu et al. 2012). Hsp110-substrate interactions are typically short-lived but can provide additional "holding" activity to the existing Jdomain protein and Hsp70 substrate interactions. Alternatively, the HSPH2-mediated release of HSPA 8 from $\alpha$ syn fibrils was strongly accelerated compared with that mediated by BAG1, even after compensating for differences in NEF activity (Gao et al. 2015). Kinetic factors relating to the rate of Hsp70 recycling may therefore provide an alternative explanation for the unique ability of Hsp110s to support disaggregation.

In bacteria, yeast, and plant cells, the Hsp70 machinery is additionally complemented by the Hsp100 $\mathrm{AAA}^{+}$ATPase that provides considerable threading power to extract polypeptides from protein aggregates (Mogk et al. 2018; Shorter and Southworth 2018). The molecular mechanism of the stand-alone HSPA8 disaggregation activity of amyloid fibrils in metazoan is, however, poorly understood. The high stability of amyloid fibrils, and the observation that the Hsp70 machinery can act along the axis of fibrils suggests that the conformational cycle of Hsp70 generates considerable pulling forces. It has been proposed that cochaperoneassisted Hsp70 binding may exert pulling forces on flexible sequences within the amyloid fibrils owing to the strong reduction in available conformational space at the fibril surface. In an attempt to reduce the entropic penalty associated with such binding events, entropic pulling forces up to $10-20 \mathrm{pN}$, which corresponds approximately to the stability of a small protein domain, may be generated to extract the bound fragment from the fibrillar core (De Los Rios et al. 2006; Goloubinoff and De Los Rios 2007; Mogk et al. 2018; Nillegoda et al. 2018). Alternative mechanisms rely on the coordinated action of Hsp70 and Hsp110 to either generate a sudden power stroke on coordinated substrate release (Gao et al. 2015), or alternate binding and release cycles that act as a ratchet for random fluctuation in the amyloid structure (Mattoo et al. 2013).

Hsp70-mediated disaggregation of $\alpha$ syn fibrils produces both monomeric and oligomeric species that, overall, have reduced cytotoxicity compared with the untreated fibrils on extracellular application (Gao et al. 2015). The oligomeric species produced may, however, act as a conformational template for further protein aggregation within the cell. Indeed, such a mechanism seems to be essential for the maintenance of prions in yeast, in which the disaggregating activity of Hsp104 produces smaller seeds that are more efficiently transmitted to daughter cells and recruit soluble proteins into the growing aggregates (Chernoff et al. 1995). Consequently, inhibiting Hsp104 function cures yeast cells of multiple yeast prions. The effect of Hsp70 disaggregation on the propagation of amyloids within metazoan host cells and the resulting cytotoxicity has thus far not been probed.

\section{ROLE OF MOLECULAR CHAPERONES IN THE DEGRADATION OF AMYLOID FORMING PROTEINS}

Alternative PQC strategies to counteract the cytotoxicity associated with protein aggregation into amyloid fibrils relies on the timely degradation of aggregation-prone soluble or aggregated species. Here, chaperones again play an essential role in substrate selection and facilitation of the degradation process.

Terminally misfolded proteins are targeted for degradation via the ubiquitin-proteasome system (UPS) or the autophagy-lysosomal pathways (ALPs). The cochaperones CHIP and BAG1 convey functional specificity to Hsp70 in 
A. Wentink et al.

targeting substrates toward proteasomal degradation (Kästle and Grune 2012). Their binding to Hsp70 slows down the protein-refolding process, which is necessary for the switch from refolding to degradation (Kästle and Grune 2012). CHIP is an E3 ubiquitin ligase that ubiquitinates both Hsp90/Hsp70/BAG1-bound substrate complexes as well as the chaperones themselves, and mediates the targeting of the complexes to the proteasome (Kästle and Grune 2012). The NEF activity of BAG1 is responsible for the release of substrates to the proteasome by decreasing the affinity of Hsp70 to the substrate (Lüders et al. 2000; Kästle and Grune 2012).

Although the UPS is only able to process monomeric protein species, it may still act on aggregates with the help of the Hsp70/Hsp110 disaggregase machinery (Hjerpe et al. 2016). Polyubiquitinated proteins that have been extracted from an aggregate by the action of Hsp70 and Hsp110 are recognized by ubiquilin 2 (UBQLN2) and shuttled to the $26 \mathrm{~S}$ proteasome (Hjerpe et al. 2016). Mutations in UBQLN2 have been linked to familial cases of ALS, highlighting the significance of this pathway for maintaining protein homeostasis in motor neurons (Deng et al. 2011).

The lysosome constitutes the cellular organelle for a second pathway of protein degradation, which not only handles monomeric substrates but also multimeric assemblies as a whole, such as oligomers and larger aggregates. Cytosolic cargo is delivered to the lysosome by a process termed autophagy, which comprises three major pathways: macroautophagy, microautophagy, and chaperone-mediated autophagy (CMA). In both microautophagy and CMA, the constitutively expressed Hsp70, HSPA8, recognizes cargo proteins by directly binding to specific motifs such as the five amino acids "KFERQ" in RNase A (Chiang and Dice 1988). In CMA, HSPA8 delivers the substrate to the lysosomal membrane protein LAMP2A (Tekirdag and Cuervo 2018). Subsequent translocation requires multimerization of LAMP2A and a pool of HSPA8, which resides in the lysosomal lumen. The exact mechanisms by which HSPA8 is transported to the lysosome and how it is able to facilitate translocation within this acidic en- vironment are unknown (Tekirdag and Cuervo 2018). Other cochaperones may be implicated in this process as well, but their exact role remains elusive (Agarraberes and Dice 2001).

In microautophagy, HSPA8 (Hsc70) targets its substrates to the endosomal membrane by electrostatic interactions with a cationic region in the substrate-binding domain (Sahu et al. 2011). Although microautophagy was first observed in yeast and describes a process in which the vacuole directly engulfs cytosolic cargo, in mammalian cells it refers to a similar process that occurs not in lysosomes, but instead in late endosomes (LEs)/multivesicular bodies (MVBs) in an ESCRT-dependent manner (Sahu et al. 2011). Therefore, it is also referred to as endosomal microautophagy in mammalian cells (eMI). In contrast to CMA, the KFERQ-like targeting motif is not sufficient for directing protein cargo to mammalian endosomes. Moreover, an unfolding of substrates is not required, allowing the recruitment of higher molecular weight complexes (Tekirdag and Cuervo 2018). Although the exact structural requirements and additional cofactors and cochaperones still await discovery, it is tempting to speculate that eMI might share components with the "misfolding-associated protein secretion” (MAPS) pathway, in which cytosolic cargo proteins likewise get targeted to the endosome, albeit for secretion (see below). This might (partially) explain the considerable cross talk between (autophagic) degradation and intercellular spreading of disease proteins (Lopes da Fonseca et al. 2015).

In addition to a sequence-mediated selection process, chaperones also play a role in targeting specific proteins to macroautophagy. This pathway involves the formation of a limiting membrane, and the sequestration of substrates within a double-membrane-bound autophagosome, which eventually fuses with the lysosome for the degradation of its contents. Macroautophagy was long considered to be an unspecific bulk degradation process of cytoplasmic material, but there is increasing evidence that cargo can be removed selectively. This is accomplished by specific adaptor proteins that recruit the substrate protein to lipidated LC3 in the autophago- 
somal membrane. For the selective clearance of aggregated proteins, including those of amyloidogenic proteins, Hsp70 functions in concert with the sHsp HSPB8 and the NEF BAG3, as well as the ubiquitin adaptor p62/SQSTM1 to deliver ubiquitinated aggregates to the autophagosome (Gamerdinger et al. 2009).

Of note, the same set of chaperones is also involved in a pathway termed "chaperone-assisted selective autophagy" (CASA) (Arndt et al. 2010), which mediates the disposal of damaged components of the $\mathrm{Z}$ disc, a large protein complex essential for muscle function, by the actininassociated LIM protein (ALP). These results imply that this chaperone network acts preferentially on large protein assemblies regardless of whether they consist of amorphous aggregates or highly ordered structures such as the $\mathrm{Z}$ disc or amyloid fibers.

In closing, it is worth mentioning that proteasomal and lysosomal degradation pathways are not mutually exclusive but rather compensate for each other (Ji and Kwon 2017). It is therefore not surprising that amyloidogenic proteins have been shown to be subjected to both proteasomal or lysosomal degradation, depending on the physiological state of the cell. Nevertheless, it is clear that the function of both pathways declines as a result of a chronic challenge by misfolded proteins or during aging. Boosting these systems might help to delay the onset of age-related diseases. The further roles of protein degradative pathways in human disease are examined in Finley (2018) and Finkbeiner (2018).

\section{SPREADING OF AMYLOID FIBRILS IS FACILITATED BY CHAPERONE MACHINERY}

In stark contrast to the various strategies by which molecular chaperones modulate the accumulation of oligomers and fibrils of amyloidogenic species in the cytoplasm stands the putative role that chaperones play in the cell-to-cell transmission of protein aggregates (Fig. 4).

Molecular chaperones, as part of their functional versatility, play important roles in processes related to cellular trafficking. Although the precise mechanism of aggregate spreading to neighboring cells is still subject of current research, different intercellular transport pathways have been identified that involve chaperones. These include a transfer of lysosome-resident aggregates through tunneling nanotubes (TNTs), which are membrane-enclosed protrusions connecting the cytosol of two cells (Fig. 4; Victoria and Zurzolo 2017). This pathway requires the accumulation of misfolded proteins within lysosomes, which at least in part requires HSPA8 (as outlined above).

An alternative route appears to be the aforementioned MAPS pathway, which mediates the secretion of cytosolic misfolded proteins by an unconventional, ER/Golgi-independent pathway (Lee et al. 2016). This pathway involves the ER-associated deubiquitinase USP19 and the pair of J-domain proteins DNAJC5 (also known as cysteine string protein $\alpha[\mathrm{CSP} \alpha]$ ) and HSPA8 (Fontaine et al. 2016; Lee et al. 2016; Xu et al.2018). MAPS substrates are first recognized by USP19 and recruited to the ER surface, and subsequently transferred to DNAJC5 (and presumably HSPA8), which localizes to LEs and mediates the uptake of cargo into the vesicle lumen. Endosomes then fuse with the plasma membrane resulting in the release of the DNAJC5/client complex into the extracellular space (Xu et al. 2018). Although these results showed the export of free proteins, another recent study found that the coexpression of DNAJC5 leads to the secretion of misfolded proteins via extracellular vesicles (Deng et al. 2017), suggesting that some cargo proteins might get sorted into intraluminal vesicles of MVBs for their release (Fig. 4).

Of note, long before being implicated in MAPS, DNAJC5 has been intensively investigated for its function in synaptic vesicle exocytosis. Genetic studies suggest that it is essential for the assembly of the soluble NSF attachment protein receptor (SNARE) complex (Sharma et al. 2012; Burgoyne and Morgan 2015). This body of work suggests that DNAJC5 could also play a more indirect role in MAPS by facilitating secretory vesicle fusion through mediating correct SNARE complex assembly.

Outside the cell, disease proteins encounter extracellular chaperones that modulate their toxicity, infectivity, and oligomeric status. ER- 
A. Wentink et al.

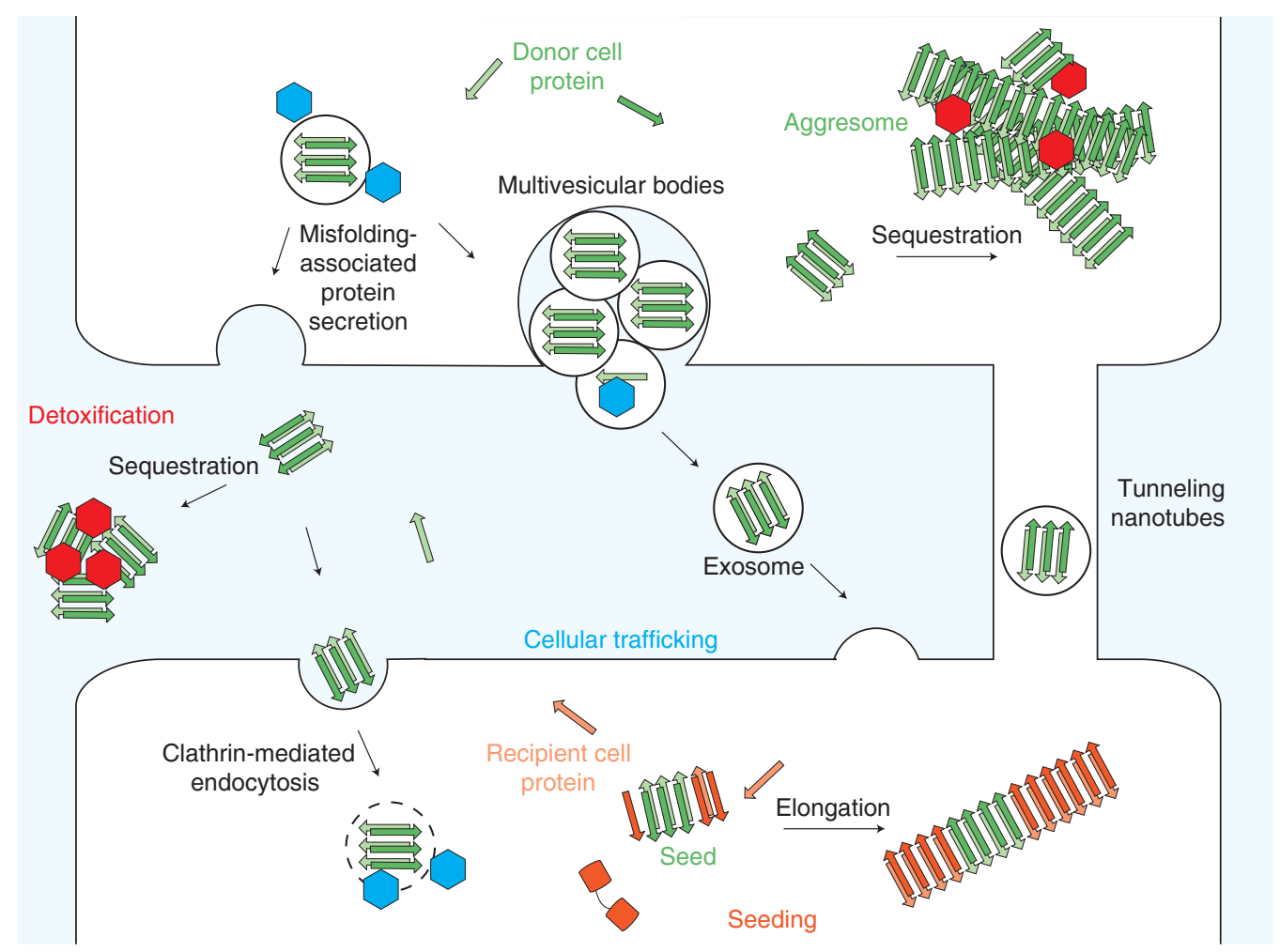

Figure 4. Role of chaperones in cellular trafficking and propagation of amyloid fibrils. Amyloidogenic species can spread from cell to cell, hijacking preexisting cellular trafficking pathways (light blue). Additional, misfolded substrate-specific pathways exist to release protein aggregates into the extracellular space. Extracellular chaperones can sequester these species into larger deposits that are less readily taken up by recipient cells (red). The successful transmission of aggregation-prone species to a naïve cell can trigger amyloid formation in this cell through templated incorporation of native monomers (orange).

resident chaperone DNAJB11 (Erdj3) can even be cosecreted with destabilized proteins under conditions of ER misfolding stress in an apparent attempt to reduce extracellular proteotoxicity (Genereux et al. 2015). A similar function can be attributed to the extracellular chaperone clusterin. Both chaperones function in an ATPindependent manner to suppress the extracellular aggregation of $A \beta$ and TTR and reduce toxicity (Yerbury et al. 2007; Narayan et al. 2012; Greene et al. 2015). Clusterin additionally acts to sequester small oligomers into large extracellular aggregates (Narayan et al. 2012) that are no longer readily taken up by recipient cells (Whiten et al. 2018). Although elevated clusterin levels in the brain of $\mathrm{AD}$ patients and the association of clusterin variants with $\mathrm{AD}$ in mul- tiple genome-wide association studies (GWAS) highlight the importance of clusterin in $\mathrm{AD}$, its exact role in disease progression needs further investigation (Yu and Tan 2012).

According to current knowledge, multiple pathways for the uptake of disease-associated proteins into recipient cells exist (Brettschneider et al. 2015). The ones involving chaperones include clathrin-mediated endocytosis (CME), in which DNAJC6 (auxilin) and HSPA8 (Hsc70) function by uncoating clathrin-coated vesicles during endocytosis (Sousa and Lafer 2015). CME is one of the pathways that has been linked to the internalization of $\alpha$ syn both, as free protein and as exosome-associated cargo (Oh et al. 2016; Ngolab et al. 2017). Moreover, mutations in DNAJC6 have been recently identified in 
GWAS for juvenile parkinsonism (PARK19) (Lin and Farrer 2014). DNAJC13 (receptormediated endocytosis-8, RME-8) is another Jdomain-protein-type cochaperone of HSPA8 that has been recently linked to familial forms of PD (PARK21) (Lin and Farrer 2014). It was first discovered in a $C$. elegans screen for genes involved in receptor-mediated endocytosis (Zhang et al. 2001). Subsequent studies point toward a more indirect effect on endocytosis by regulating downstream endosomal tubulation and sorting of cargo proteins (Shi et al. 2009; Freeman et al. 2014). However, how alterations in endosomal trafficking and homeostasis caused by dysfunctional DNAJC13 might aggravate asyn-induced neurotoxicity, and whether it is implicated in osyn spreading needs further investigation. Moreover, although these reports underscore the significance of the endocytic/endosomal vesicle trafficking pathway in synucleinopathies and reveal a role of particular Hsp70 cochaperones specific to these diseases, their implication in the toxicity and spreading of amyloidogenic proteins associated with other neurodegenerative diseases remains to be proven.

\section{CONCLUSION AND PERSPECTIVES}

Amyloid formation is a complex process that presents a multitude of opportunities for intervention. What becomes apparent is both the diversity in molecular mechanisms and the functional versatility of chaperones that interfere in this process. With this flexibility comes the caveat that the cellular outcome of chaperone action is a complex summation of various, often competing activities. The therapeutic potential of chaperones to suppress protein aggregation in the context of neurodegeneration will therefore hinge on our ability to grasp the complex interplay of the various chaperoning mechanisms and the identification of factors that may provide functional specificity such as the cochaperones. A promising example of such an approach is the development of a small molecule inhibitor of the Hsp90 cochaperone Aha1, which reduces tau aggregation in vitro, cell culture, and mouse model of AD by enhancing monomeric tau degradation (Shelton et al. 2017).
An additional layer of complexity stems from our current inability to unequivocal attribute cytotoxicity to one or more aggregate states produced along the amyloid formation pathway. The emerging theory that the cytotoxicity observed in neurodegeneration is predominantly caused by oligomers or prefibrillar species rather than amyloid fibrils would suggest that while preventing initial aggregation is the holy grail to combat aggregation associated diseases, promoting the more rapid conversion to the amyloid state by suppressing chaperoning activities that prevent fibril elongation may be an alternative strategy to minimize cytotoxicity in later stages of disease progression.

With our current level of mechanistic insight, we can begin to envisage specific therapeutic strategies designed to replicate chaperone activities by small molecules. This includes chemicals and peptides designed to inhibit aggregation (Briggs et al. 2016; Valera and Masliah 2016) or small protein domains engineered to sequester and neutralize protein aggregates or assist in the intra- and extracellular clearance (Messer and Joshi 2013; Manoutcharian et al. 2017). All these developments will be much aided by a better understanding of the effects of the global cellular environment on the aggregation process, as the highly ordered amyloid fibrils discussed in this review are likely to represent only a fraction of the protein aggregate populations present in neurodegeneration.

\section{ACKNOWLEDGMENTS}

This work was supported by grants of the Deutsche Forschungsgemeinschaft (DFG) Collaborative Research Center SFB1036 TP8 and TP20 to B.B. and C.N.-K., respectively, the Baden-Württemberg Stiftung (BWST-ISFIII-029), and the Alzheimer Forschung Initiative e.V. (AFI, 17054). We thank Axel Mogk for critical reading of the manuscript.

\section{REFERENCES}

${ }^{*}$ Reference is also in this collection.

Agarraberes FA, Dice JF. 2001. A molecular chaperone complex at the lysosomal membrane is required for protein translocation. J Cell Sci 114: 2491-2499. 
A. Wentink et al.

Altieri F, Di Stadio CS, Severino V, Sandomenico A, Minopoli G, Miselli G, Di Maro A, Ruvo M, Chambery A, Quagliariello V, et al. 2014. Anti-amyloidogenic property of human gastrokine 1. Biochimie 106: 91-100. doi: 10.1016/j.biochi.2014.08.004

Aprile FA, Källstig E, Limorenko G, Vendruscolo M, Ron D, Hansen C. 2017. The molecular chaperones DNAJB6 and Hsp70 cooperate to suppress $\alpha$-synuclein aggregation. Sci Rep 7: 9039. doi:10.1038/s41598-017-08324-z

Arndt V, Dick N, Tawo R, Dreiseidler M, Wenzel D, Hesse M, Furst DO, Saftig P, Saint R, Fleischmann BK, et al. 2010. Chaperone-assisted selective autophagy is essential for muscle maintenance. Curr Biol 20: 143-148. doi: 10.1016/j.cub.2009.11.022

Arosio P, Michaels TC, Linse S, Månsson C, Emanuelsson C, Presto J, Johansson J, Vendruscolo M, Dobson CM, Knowles TP. 2016. Kinetic analysis reveals the diversity of microscopic mechanisms through which molecular chaperones suppress amyloid formation. Nat Commun 7: 10948. doi:10.1038/ncomms10948

Arrasate M, Mitra S, Schweitzer ES, Segal MR, Finkbeiner S. 2004. Inclusion body formation reduces levels of mutant huntingtin and the risk of neuronal death. Nature 431: 805-810. doi:10.1038/nature02998

Balchin D, Hayer-Hartl M, Hartl FU. 2016. In vivo aspects of protein folding and quality control. Science 353: aac4354. doi:10.1126/science.aac4354

Baldwin AJ, Knowles TP, Tartaglia GG, Fitzpatrick AW, Devlin GL, Shammas SL, Waudby CA, Mossuto MF, Meehan S, Gras SL, et al. 2011. Metastability of native proteins and the phenomenon of amyloid formation. $J$ Am Chem Soc 133: 14160-14163. doi:10.1021/ja2017703

Baughman HER, Clouser AF, Klevit RE, Nath A. 2018. $\mathrm{HspB} 1$ and $\mathrm{Hsc} 70$ chaperones engage distinct tau species and have different inhibitory effects on amyloid formation. J Biol Chem 293: 2687-2700. doi:10.1074/jbc. M117.803411

Beeg M, Stravalaci M, Romeo M, Carra AD, Cagnotto A, Rossi A, Diomede L, Salmona M, Gobbi M. 2016. Clusterin binds to $A \beta_{1-42}$ oligomers with high affinity and interferes with peptide aggregation by inhibiting primary and secondary nucleation. J Biol Chem 291: 6958-6966. doi:10.1074/jbc.M115.689539

Behrends C, Langer CA, Boteva R, Bottcher UM, Stemp MJ, Schaffar G, Rao BV, Giese A, Kretzschmar H, Siegers K, et al. 2006. Chaperonin TRiC promotes the assembly of polyQ expansion proteins into nontoxic oligomers. $\mathrm{Mol}$ Cell 23: 887-897. doi:10.1016/j.molcel.2006.08.017

Ben-Zvi A, Miller EA, Morimoto RI. 2009. Collapse of proteostasis represents an early molecular event in Caenorhabditis elegans aging. Proc Natl Acad Sci 106: 1491414919. doi:10.1073/pnas.0902882106

* Biebl MM, Buchner J. 2018. Structure, function, and regulation of the Hsp90 machinery. Cold Spring Harb Perspect Biol doi:10.1101/cshperspect.a034017

Blake MJ, Udelsman R, Feulner GJ, Norton DD, Holbrook NJ. 1991. Stress-induced heat shock protein 70 expression in adrenal cortex: An adrenocorticotropic hormone-sensitive, age-dependent response. Proc Natl Acad Sci 88: 9873-9877. doi:10.1073/pnas.88.21.9873
Blancas-Mejía LM, Ramirez-Alvarado M. 2013. Systemic amyloidoses. Annu Rev Biochem 82: 745-774. doi: 10.1146/annurev-biochem-072611-130030

Brettschneider J, Del Tredici K, Lee VM, Trojanowski JQ. 2015. Spreading of pathology in neurodegenerative diseases: A focus on human studies. Nat Rev Neurosci 16: 109-120. doi:10.1038/nrn3887

Briggs R, Kennelly SP, O’Neill D. 2016. Drug treatments in Alzheimer's disease. Clin Med (Lond) 16: 247-253. doi: 10.7861/clinmedicine.16-3-247

Bruinsma IB, Bruggink KA, Kinast K, Versleijen AA, SegersNolten IM, Subramaniam V, Kuiperij HB, Boelens W, de Waal RM, Verbeek MM. 2011. Inhibition of $\alpha$-synuclein aggregation by small heat shock proteins. Proteins 79: 2956-2967. doi:10.1002/prot.23152

Brundin P, Melki R, Kopito R. 2010. Prion-like transmission of protein aggregates in neurodegenerative diseases. Nat Rev Mol Cell Biol 11: 301-307. doi:10.1038/nrm2873

Bukau B, Weissman J, Horwich A. 2006. Molecular chaperones and protein quality control. Cell 125: 443-451. doi: 10.1016/j.cell.2006.04.014

Burgoyne RD, Morgan A. 2015. Cysteine string protein (CSP) and its role in preventing neurodegeneration. Semin Cell Dev Biol 40: 153-159. doi:10.1016/j.semc db.2015.03.008

Campioni S, Mannini B, Zampagni M, Pensalfini A, Parrini C, Evangelisti E, Relini A, Stefani M, Dobson CM, Cecchi C, et al. 2010. A causative link between the structure of aberrant protein oligomers and their toxicity. Nat Chem Biol 6: 140-147. doi:10.1038/nchembio.283

Carulla N, Caddy GL, Hall DR, Zurdo J, Gairí M, Feliz M, Giralt E, Robinson CV, Dobson CM. 2005. Molecular recycling within amyloid fibrils. Nature 436: 554-558. doi:10.1038/nature03986

Chafekar SM, Duennwald ML. 2012. Impaired heat shock response in cells expressing full-length polyglutamineexpanded huntingtin. PLoS ONE 7: e37929. doi: 10.1371/journal.pone.0037929

Chen S, Ferrone FA, Wetzel R. 2002. Huntington's disease age-of-onset linked to polyglutamine aggregation nucleation. Proc Natl Acad Sci 99: 11884-11889. doi:10.1073/ pnas. 182276099

Chen JJ, Genereux JC, Suh EH, Vartabedian VF, Rius B, Qu S, Dendle MTA, Kelly JW, Wiseman RL. 2016. Endoplasmic reticulum proteostasis influences the oligomeric state of an amyloidogenic protein secreted from mammalian cells. Cell Chem Biol 23: 1282-1293. doi:10.1016/j.chembiol.2016.09.001

Chernoff YO, Lindquist SL, Ono B, Inge-Vechtomov SG, Liebman SW. 1995. Role of the chaperone protein Hsp104 in propagation of the yeast prion-like factor [psi+]. Science 268: 880-884. doi:10.1126/science. 7754373

Chiang HL, Dice JF. 1988. Peptide sequences that target proteins for enhanced degradation during serum withdrawal. J Biol Chem 263: 6797-6805.

Chien V, Aitken JF, Zhang S, Buchanan CM, Hickey A, Brittain T, Cooper GJ, Loomes KM. 2010. The chaperone proteins HSP70, HSP40/DnaJ and GRP78/BiP suppress misfolding and formation of $\beta$-sheet-containing aggregates by human amylin: A potential role for defective 
chaperone biology in type 2 diabetes. Biochem J 432: 113121. doi:10.1042/BJ20100434

Chiti F, Dobson CM. 2017. Protein misfolding, amyloid formation, and human disease: A summary of progress over the last decade. Annu Rev Biochem 86: 27-68. doi:10.1146/annurev-biochem-061516-045115

Cohen E, Dillin A. 2008. The insulin paradox: Aging, proteotoxicity and neurodegeneration. Nat Rev Neurosci 9: 759-767. doi:10.1038/nrn2474

Cohen SI, Linse S, Luheshi LM, Hellstrand E, White DA, Rajah L, Otzen DE, Vendruscolo M, Dobson CM, Knowles TP. 2013. Proliferation of amyloid- $\beta 42$ aggregates occurs through a secondary nucleation mechanism. Proc Natl Acad Sci 110: 9758-9763. doi:10.1073/pnas. 1218402110

Cohen SIA, Arosio P, Presto J, Kurudenkandy FR, Biverstal H, Dolfe L, Dunning C, Yang X, Frohm B, Vendruscolo $\mathrm{M}$, et al. 2015. A molecular chaperone breaks the catalytic cycle that generates toxic $\mathrm{A} \beta$ oligomers. Nat Struct Mol Biol 22: 207-213. doi:10.1038/nsmb.2971

Cox D, Selig E, Griffin MD, Carver JA, Ecroyd H. 2016. Small heat-shock proteins prevent $\alpha$-synuclein aggregation via transient interactions and their efficacy is affected by the rate of aggregation. J Biol Chem 291: 22618-22629. doi:10.1074/jbc.M116.739250

Cox D, Whiten DR, Brown JWP, Horrocks MH, San Gil R, Dobson CM, Klenerman D, van Oijen AM, Ecroyd H 2018. The small heat shock protein Hsp27 binds $\alpha$ synuclein fibrils, preventing elongation and cytotoxicity. J Biol Chem 293: 4486-4497. doi:10.1074/jbc.M117. 813865

Cremades N, Cohen SI, Deas E, Abramov AY, Chen AY, Orte A, Sandal M, Clarke RW, Dunne P, Aprile FA, et al. 2012. Direct observation of the interconversion of normal and toxic forms of $\alpha$-synuclein. Cell 149: 1048-1059. doi:10.1016/j.cell.2012.03.037

Daturpalli S, Waudby CA, Meehan S, Jackson SE. 2013. Hsp90 inhibits $\alpha$-synuclein aggregation by interacting with soluble oligomers. J Mol Biol 425: 4614-4628. doi:10.1016/j.jmb.2013.08.006

Davis PD, Raffen R, Dul LJ, Vogen MS, Williamson KE, Stevens JF, Argon Y. 2000. Inhibition of amyloid fiber assembly by both $\mathrm{BiP}$ and its target peptide. Immunity 13: 433-442. doi:10.1016/S1074-7613(00)00043-1

Dedmon MM, Christodoulou J, Wilson MR, Dobson CM. 2005. Heat shock protein 70 inhibits $\alpha$-synuclein fibril formation via preferential binding to prefibrillar species. $J$ Biol Chem 280: 14733-14740. doi:10.1074/jbc. M413024200

De Los Rios P, Ben-Zvi A, Slutsky O, Azem A, Goloubinoff P. 2006. Hsp70 chaperones accelerate protein translocation and the unfolding of stable protein aggregates by entropic pulling. Proc Natl Acad Sci 103: 6166-6171. doi:10.1073/ pnas.0510496103

Deng HX, Chen W, Hong ST, Boycott KM, Gorrie GH, Siddique N, Yang Y, Fecto F, Shi Y, Zhai H, et al. 2011. Mutations in UBQLN2 cause dominant X-linked juvenile and adult-onset ALS and ALS/dementia. Nature 477: 211-215. doi:10.1038/nature10353

Deng J, Koutras C, Donnelier J, Alshehri M, Fotouhi M, Girard M, Casha S, McPherson PS, Robbins SM, Braun JEA. 2017. Neurons export extracellular vesicles enriched in cysteine string protein and misfolded protein cargo. Sci Rep 7: 956. doi:10.1038/s41598-017-01115-6

* Dobson C. 2018. Amyloid phenomenon and significance for human disease. Cold Spring Harb Perspect Biol doi: 10.1101/cshpersect.a033878

Duennwald ML, Echeverria A, Shorter J. 2012. Small heat shock proteins potentiate amyloid dissolution by protein disaggregases from yeast and humans. PLoS Biol 10: e1001346. doi:10.1371/journal.pbio.1001346

Eichner T, Radford SE. 2011. A diversity of assembly mechanisms of a generic amyloid fold. Mol Cell 43: 8-18. doi:10.1016/j.molcel.2011.05.012

* Eisenberg D. 2018. Structural insights in amyloids and prion diseases. Cold Spring Harb Perspect Biol 7 doi:10.1101/ cshpersect.a033852

Eisenberg DS, Sawaya MR. 2017. Structural studies of amyloid proteins at the molecular level. Annu Rev Biochem 86: 69-95. doi:10.1146/annurev-biochem-061516-045104

Escusa-Toret S, Vonk WI, Frydman J. 2013. Spatial sequestration of misfolded proteins by a dynamic chaperone pathway enhances cellular fitness during stress. Nat Cell Biol 15: 1231-1243. doi:10.1038/ncb2838

Evans KC, Berger EP, Cho CG, Weisgraber KH, Lansbury PT. 1995. Apolipoprotein E is a kinetic but not a thermodynamic inhibitor of amyloid formation: Implications for the pathogenesis and treatment of Alzheimer disease. Proc Natl Acad Sci 92: 763-767. doi:10.1073/pnas.92. 3.763

Evans CG, Wisén S, Gestwicki JE. 2006. Heat shock proteins 70 and 90 inhibit early stages of amyloid $\beta-(1-42)$ aggregation in vitro. J Biol Chem 281: 33182-33191. doi: 10.1074/jbc.M606192200

Falsone SF, Kungl AJ, Rek A, Cappai R, Zangger K. 2009. The molecular chaperone Hsp90 modulates intermediate steps of amyloid assembly of the Parkinson-related protein $\alpha$-synuclein. J Biol Chem 284: 31190-31199. doi:10.1074/jbc.M109.057240

* Finkbeiner S. 2018. Autophagy lysosomal pathways and neurodegeneration. Cold Spring Harb Perspect Biol doi: 10.1101/cshperspect.a033993

* Finley D. 2018. Ubiquitin proteasome and the remodeling of life. Cold Spring Harb Perspect Biol doi:10.1101/cshperspect.a033985

Fitzpatrick AWP, Falcon B, He S, Murzin AG, Murshudov G, Garringer HJ, Crowther RA, Ghetti B, Goedert M, Scheres SHW. 2017. Cryo-EM structures of tau filaments from Alzheimer's disease. Nature 547: 185-190. doi:10.1038/ nature23002

Fontaine SN, Zheng D, Sabbagh JJ, Martin MD, Chaput D, Darling A, Trotter JH, Stothert AR, Nordhues BA, Lussier A, et al. 2016. DnaJ/Hsc70 chaperone complexes control the extracellular release of neurodegenerative-associated proteins. $E M B O J$ 35: 1537-1549. doi:10.15252/embj. 201593489

Freeman CL, Hesketh G, Seaman MN. 2014. RME-8 coordinates the activity of the WASH complex with the function of the retromer SNX dimer to control endosomal tubulation. J Cell Sci 127: 2053-2070. doi:10.1242/ jcs.144659

Fujikake N, Nagai Y, Popiel HA, Okamoto Y, Yamaguchi M, Toda T. 2008. Heat shock transcription factor 1-activating 
A. Wentink et al.

compounds suppress polyglutamine-induced neurodegeneration through induction of multiple molecular chaperones. J Biol Chem 283: 26188-26197. doi: 10.1074/jbc.M710521200

Gamerdinger M, Hajieva P, Kaya AM, Wolfrum U, Hartl FU, Behl C. 2009. Protein quality control during aging involves recruitment of the macroautophagy pathway by BAG3. EMBO J 28: 889-901. doi:10.1038/emboj.2009.29

Gamerdinger M, Kaya AM, Wolfrum U, Clement AM, Behl C. 2011. BAG3 mediates chaperone-based aggresometargeting and selective autophagy of misfolded proteins. EMBO Rep 12: 149-156. doi:10.1038/embor.2010.203

Gao X, Carroni M, Nussbaum-Krammer C, Mogk A, Nillegoda NB, Szlachcic A, Guilbride DL, Saibil HR, Mayer MP, Bukau B. 2015. Human Hsp70 disaggregase reverses Parkinson's-linked $\alpha$-synuclein amyloid fibrils. Mol Cell 59: 781-793. doi:10.1016/j.molcel.2015.07.012

Gath J, Bousset L, Habenstein B, Melki R, Bockmann A, Meier BH. 2014. Unlike twins: An NMR comparison of two $\alpha$-synuclein polymorphs featuring different toxicity. PLOS ONE 9: e90659. doi:10.1371/journal.pone.0090659

Genereux JC, Qu S, Zhou M, Ryno LM, Wang S, Shoulders MD, Kaufman RJ, Lasmezas CI, Kelly JW, Wiseman RL. 2015. Unfolded protein response-induced ERdj3 secretion links ER stress to extracellular proteostasis. EMBO 34: 4-19. doi:10.15252/embj.201488896

Gillis J, Schipper-Krom S, Juenemann K, Gruber A, Coolen $S$, van den Nieuwendijk R, van Veen $H$, Overkleeft $H$, Goedhart J, Kampinga HH, et al. 2013. The DNAJB6 and DNAJB8 protein chaperones prevent intracellular aggregation of polyglutamine peptides. J Biol Chem 288: 17225-17237. doi:10.1074/jbc.M112.421685

Goedert M, Clavaguera F, Tolnay M. 2010. The propagation of prion-like protein inclusions in neurodegenerative diseases. Trends Neurosci 33: 317-325. doi:10.1016/j. tins.2010.04.003

Goloubinoff P, De Los Rios P. 2007. The mechanism of Hsp70 chaperones: (Entropic) pulling the models together. Trends Biochem Sci 32: 372-380. doi:10.1016/j. tibs.2007.06.008

Greene MJ, Klimtchuk ES, Seldin DC, Berk JL, Connors LH. 2015. Cooperative stabilization of transthyretin by clusterin and diflunisal. Biochemistry 54: 268-278. doi: 10.1021/bi5011249

Gremer L, Scholzel D, Schenk C, Reinartz E, Labahn J, Ravelli RBG, Tusche M, Lopez-Iglesias C, Hoyer W, Heise H, et al. 2017. Fibril structure of amyloid- $\beta(1-42)$ by cryoelectron microscopy. Science 358: 116-119. doi:10.1126/ science.aao 2825

Guerrero-Ferreira R, Taylor NMI, Mona D, Ringler P, Lauer ME, Riek R, Britschgi M, Stahlberg H. 2018. Cryo-EM structure of $\alpha$-synuclein fibrils. eLife 7: e36402. doi: 10.7554/eLife.36402

Guo Q, Lehmer C, Martinez-Sanchez A, Rudack T, Beck F, Hartmann H, Perez-Berlanga M, Frottin F, Hipp MS Hartl FU, et al. 2018. In situ structure of neuronal C9orf72 poly-GA aggregates reveals proteasome recruitment. Cell 172: 696-705.e12. doi:10.1016/j.cell.2017.12. 030

* Hartl U. 2018. Protein folding and misfolding in the cytoplasm. Cold Spring Harb Perspect Biol doi: 10.1101/ cshperspect.a033951
Hartl F, Bracher A. 2011. Molecular chaperones in protein folding and proteostasis. Nature 475: 324-332. doi: 10.1038/nature10317

Hay DG, Sathasivam K, Tobaben S, Stahl B, Marber M, Mestril R, Mahal A, Smith DL, Woodman B, Bates GP. 2004. Progressive decrease in chaperone protein levels in a mouse model of Huntington's disease and induction of stress proteins as a therapeutic approach. Hum Mol Genet 13: 1389-1405. doi:10.1093/hmg/ddh144

Helwig M, Hoshino A, Berridge C, Lee SN, Lorenzen N, Otzen DE, Eriksen JL, Lindberg I. 2013. The neuroendocrine protein $7 \mathrm{~B} 2$ suppresses the aggregation of neurodegenerative disease-related proteins. J Biol Chem 288: 1114-1124. doi:10.1074/jbc.M112.417071

Hinault MP, Cuendet AF, Mattoo RU, Mensi M, Dietler G, Lashuel HA, Goloubinoff P. 2010. Stable $\alpha$-synuclein oligomers strongly inhibit chaperone activity of the Hsp70 system by weak interactions with J-domain co-chaperones. J Biol Chem 285: 38173-38182. doi: 10.1074/jbc.M110.127753

Hipp MS, Park SH, Hartl FU. 2014. Proteostasis impairment in protein-misfolding and -aggregation diseases. Trends Cell Biol 24: 506-514. doi:10.1016/j.tcb.2014.05.003

Hjerpe R, Bett JS, Keuss MJ, Solovyova A, McWilliams TG, Johnson C, Sahu I, Varghese J, Wood N, Wightman M, et al. 2016. UBQLN2 mediates autophagy-independent protein aggregate clearance by the proteasome. Cell 166: 935949. doi:10.1016/j.cell.2016.07.001

Hughes SR, Khorkova O, Goyal S, Knaeblein J, Heroux J, Riedel NG, Sahasrabudhe S. 1998. $\alpha 2$-macroglobulin associates with $\beta$-amyloid peptide and prevents fibril formation. Proc Natl Acad Sci 95: 3275-3280. doi:10.1073/ pnas.95.6.3275

* Janowska MK, Baughman HER, Woods CN, Klevit RE. 2018. Mechanisms of small heat shock proteins. Cold Spring Harb Perspect Biol doi: 10.1101/cshperspect. a034025

Ji CH, Kwon YT. 2017. Crosstalk and interplay between the ubiquitin-proteasome system and autophagy. Mol Cells 40: 441-449.

Jiang YQ, Wang XL, Cao XH, Ye ZY, Li L, Cai WQ. 2013. Increased heat shock transcription factor 1 in the cerebellum reverses the deficiency of Purkinje cells in Alzheimer's disease. Brain Res 1519: 105-111. doi:10.1016/ j.brainres.2013.04.059

Jinwal UK, Koren J III, Borysov SI, Schmid AB, Abisambra JF, Blair LJ, Johnson AG, Jones JR, Shults CL, O'Leary JC III, et al. 2010. The Hsp90 cochaperone, FKBP51, increases Tau stability and polymerizes microtubules. J Neurosci 30: 591-599. doi:10.1523/jneuroscI.4815-09.2010

Jinwal UK, Akoury E, Abisambra JF, O’Leary JC III, Thompson AD, Blair LJ, Jin Y, Bacon J, Nordhues BA, Cockman $\mathrm{M}$, et al. 2013. Imbalance of Hsp70 family variants fosters tau accumulation. FASEB J 27: 1450-1459. doi:10.1096/ fj.12-220889

Johnston JA, Ward CL, Kopito RR. 1998. Aggresomes: A cellular response to misfolded proteins. J Cell Biol 143: 1883-1898. doi:10.1083/jcb.143.7.1883

* Joutsen J, Sistonen L. 2018. Tailoring of proteostasis networks with heat shock factors. Cold Spring Harb Perspect Biol doi: 10.1101/cshperspect.a034066 
Kakkar V, Meister-Broekema M, Minoia M, Carra S, Kampinga HH. 2014. Barcoding heat shock proteins to human diseases: looking beyond the heat shock response. Dis Model Mech 7: 421-434. doi:10.1242/dmm.014563

Kakkar V, Mansson C, de Mattos EP, Bergink S, van der Zwaag M, van Waarde MA, Kloosterhuis NJ, Melki R, van Cruchten RT, Al-Karadaghi S, et al. 2016. The S/Trich motif in the DNAJB6 chaperone delays polyglutamine aggregation and the onset of disease in a mouse model. Mol Cell 62: 272-283. doi:10.1016/j.molcel. 2016.03.017

Kampinga HH, Bergink S. 2016. Heat shock proteins as potential targets for protective strategies in neurodegeneration. Lancet Neurol 15: 748-759. doi:10.1016/S14744422(16)00099-5

Kampinga HH, Craig EA. 2010. The HSP70 chaperone machinery: J proteins as drivers of functional specificity. Nat Rev Mol Cell Biol 11: 579-592. doi:10.1038/nrm2941

Karagoz GE, Duarte AMS, Akoury E, Ippel H, Biernat J, Luengo TM, Radli M, Didenko T, Nordhues BA, Veprintsev DB, et al. 2014. Hsp90-tau complex reveals molecular basis for specificity in chaperone action. Cell 156: 963974. doi:10.1016/j.cell.2014.01.037

Kästle M, Grune T. 2012. Interactions of the proteasomal system with chaperones: Protein triage and protein quality control. Prog Mol Biol Transl Sci 109: 113-160. doi:10.1016/B978-0-12-397863-9.00004-3

Kim YE, Hosp F, Frottin F, Ge H, Mann M, Hayer-Hartl M, Hartl FU. 2016. Soluble oligomers of polyQ-expanded huntingtin target a multiplicity of key cellular factors. Mol Cell 63: 951-964. doi:10.1016/j.molcel.2016.07.022

Kirstein J, Arnsburg K, Scior A, Szlachcic A, Guilbride DL, Morimoto RI, Bukau B, Nillegoda NB. 2017. In vivo properties of the disaggregase function of J-proteins and Hsc70 in Caenorhabditis elegans stress and aging. Aging Cell 16: 1414-1424. doi:10.1111/acel.12686

Knowles TP, Waudby CA, Devlin GL, Cohen SI, Aguzzi A, Vendruscolo M, Terentjev EM, Welland ME, Dobson CM. 2009. An analytical solution to the kinetics of breakable filament assembly. Science 326: 1533-1537. doi:10.1126/science.1178250

Knowles TP, Vendruscolo M, Dobson CM. 2014. The amyloid state and its association with protein misfolding diseases. Nat Rev Mol Cell Biol 15: 384-396. doi:10.1038/ nrm3810

Kopito RR. 2000. Aggresomes, inclusion bodies and protein aggregation. Trends Cell Biol 10: 524-530. doi:10.1016/ S0962-8924(00)01852-3

Kumita JR, Poon S, Caddy GL, Hagan CL, Dumoulin M, Yerbury JJ, Stewart EM, Robinson CV, Wilson MR, Dobson CM. 2007. The extracellular chaperone clusterin potently inhibits human lysozyme amyloid formation by interacting with prefibrillar species. J Mol Biol 369: 157-167. doi:10.1016/j.jmb.2007.02.095

Labbadia J, Morimoto RI. 2015. The biology of proteostasis in aging and disease. Annu Rev Biochem 84: 435-464. doi:10.1146/annurev-biochem-060614-033955

Labbadia J, Novoselov SS, Bett JS, Weiss A, Paganetti P, Bates GP, Cheetham ME. 2012. Suppression of protein aggregation by chaperone modification of high molecular weight complexes. Brain 135: 1180-1196. doi:10.1093/ brain/aws 022
Lashuel HA, Overk CR, Oueslati A, Masliah E. 2013. The many faces of $\alpha$-synuclein: From structure and toxicity to therapeutic target. Nat Rev Neurosci 14: 38-48. doi: 10.1038/nrn3406

Lee YK, Brewer JW, Hellman R, Hendershot LM. 1999. BiP and immunoglobulin light chain cooperate to control the folding of heavy chain and ensure the fidelity of immunoglobulin assembly. Mol Biol Cell 10: 2209-2219. doi:10.1091/mbc.10.7.2209

Lee S, Carson K, Rice-Ficht A, Good T. 2005. Hsp20, a novel $\alpha$-crystallin, prevents $A \beta$ fibril formation and toxicity. Protein Sci 14: 593-601. doi:10.1110/ps.041020705

Lee JG, Takahama S, Zhang G, Tomarev SI, Ye Y. 2016. Unconventional secretion of misfolded proteins promotes adaptation to proteasome dysfunction in mammalian cells. Nat Cell Biol 18: 765-776. doi:10.1038/ncb3372

Li J, Soroka J, Buchner J. 2012. The Hsp90 chaperone machinery: Conformational dynamics and regulation by co-chaperones. Biochim Biophys Acta 1823: 624-635. doi:10.1016/j.bbamcr.2011.09.003

Liangliang X, Yonghui H, Shunmei E, Shoufang G, Wei Z, Jiangying Z. 2010. Dominant-positive HSF1 decreases $\alpha$ synuclein level and $\alpha$-synuclein-induced toxicity. $\mathrm{Mol}$ Biol Rep 37: 1875-1881. doi:10.1007/s11033-009-9623-2

Lin MK, Farrer MJ. 2014. Genetics and genomics of Parkinson's disease. Genome Med 6: 48. doi:10.1186/gm566

Lopes da Fonseca T, Villar-Piqué A, Outeiro TF. 2015. The Interplay between $\alpha$-synuclein clearance and spreading. Biomolecules 5: 435-471. doi:10.3390/biom5020435

Lüders J, Demand J, Hohfeld J. 2000. The ubiquitin-related BAG-1 provides a link between the molecular chaperones Hsc70/Hsp70 and the proteasome. J Biol Chem 275: 4613-4617. doi:10.1074/jbc.275.7.4613

Luheshi LM, Hoyer W, de Barros TP, van Dijk Hard I, Brorsson AC, Macao B, Persson C, Crowther DC, Lomas DA, Stahl S, et al. 2010. Sequestration of the A $\beta$ peptide prevents toxicity and promotes degradation in vivo. PLoS Biol 8: e1000334. doi:10.1371/journal.pbio.1000334

Luhrs T, Ritter C, Adrian M, Riek-Loher D, Bohrmann B, Dobeli H, Schubert D, Riek R. 2005. 3D structure of Alzheimer's amyloid- $\beta(1-42)$ fibrils. Proc Natl Acad Sci 102: 17342-17347. doi:10.1073/pnas.0506723102

Mainz A, Peschek J, Stavropoulou M, Back KC, Bardiaux B, Asami S, Prade E, Peters C, Weinkauf S, Buchner J, et al. 2015. The chaperone $\alpha \mathrm{B}$-crystallin uses different interfaces to capture an amorphous and an amyloid client. Nat Struct Mol Biol 22: 898-905. doi:10.1038/nsmb.3108

Mannini B, Cascella R, Zampagni M, van Waarde-Verhagen M, Meehan S, Roodveldt C, Campioni S, Boninsegna M, Penco A, Relini A, et al. 2012. Molecular mechanisms used by chaperones to reduce the toxicity of aberrant protein oligomers. Proc Natl Acad Sci 109: 1247912484. doi:10.1073/pnas.1117799109

Manoutcharian K, Perez-Garmendia R, Gevorkian G. 2017. Recombinant antibody fragments for neurodegenerative diseases. Curr Neuropharmacol 15: 779-788. doi:10.2174/ 1570159X01666160930121647

Månsson C, Arosio P, Hussein R, Kampinga HH, Hashem RM, Boelens WC, Dobson CM, Knowles TP, Linse S, Emanuelsson C. 2014a. Interaction of the molecular chaperone DNAJB6 with growing amyloid- $\beta 42$ (A $\beta 42)$ aggregates leads to sub-stoichiometric inhibition of amy- 
A. Wentink et al.

loid formation. J Biol Chem 289: 31066-31076. doi: 10.1074/jbc.M114.595124

Månsson C, Kakkar V, Monsellier E, Sourigues Y, Harmark J, Kampinga HH, Melki R, Emanuelsson C. 2014b. DNAJB6 is a peptide-binding chaperone which can suppress amyloid fibrillation of polyglutamine peptides at substoichiometric molar ratios. Cell Stress Chaperones 19: 227-239. doi:10.1007/s12192-013-0448-5

Månsson C, van Cruchten RTP, Weininger U, Yang X, Cukalevski R, Arosio P, Dobson CM, Knowles T, Akke M, Linse $\mathrm{S}$, et al. 2018. Conserved S/T residues of the human chaperone DNAJB6 are required for effective inhibition of A 42 amyloid fibril formation. Biochemistry 57: 48914902. doi:10.1021/acs.biochem.8b00353

Mao X, Ou MT, Karuppagounder SS, Kam TI, Yin X, Xiong Y, Ge P, Umanah GE, Brahmachari S, Shin JH, et al. 2016. Pathological $\alpha$-synuclein transmission initiated by binding lymphocyte-activation gene 3. Science 353: aah3374.

Martin EM, Jackson MP, Gamerdinger M, Gense K, Karamonos TK, Humes JR, Deuerling E, Ashcroft AE, Radford SE. 2018. Conformational flexibility within the nascent polypeptide-associated complex enables its interactions with structurally diverse client proteins. J Biol Chem 293: $8554-8568$. doi:10.1074/jbc.RA117.001568

Mattoo RU, Goloubinoff P. 2014. Molecular chaperones are nanomachines that catalytically unfold misfolded and alternatively folded proteins. Cell Mol Life Sci 71: 33113325. doi:10.1007/s00018-014-1627-y

Mattoo RU, Sharma SK, Priya S, Finka A, Goloubinoff P. 2013. Hsp110 is a bona fide chaperone using ATP to unfold stable misfolded polypeptides and reciprocally collaborate with Hsp70 to solubilize protein aggregates. $J$ Biol Chem 288: 21399-21411. doi:10.1074/jbc. M113.479253

Melki R. 2018. How the shapes of seeds can influence pathology. Neurobiol Dis 109: 201-208. doi:10.1016/j. nbd.2017.03.011

Melnick J, Dul JL, Argon Y. 1994. Sequential interaction of the chaperones BiP and GRP94 with immunoglobulin chains in the endoplasmic reticulum. Nature 370: 373375. doi:10.1038/370373a0

Messer A, Joshi SN. 2013. Intrabodies as neuroprotective therapeutics. Neurotherapeutics 10: 447-458. doi: 10.1007/s13311-013-0193-6

Miller SB, Ho CT, Winkler J, Khokhrina M, Neuner A, Mohamed MY, Guilbride DL, Richter K, Lisby M, Schiebel E, et al. 2015. Compartment-specific aggregases direct distinct nuclear and cytoplasmic aggregate deposition. EMBO J 34: 778-797. doi:10.15252/embj.201489524

Mogk A, Bukau B, Kampinga HH. 2018. Cellular handling of protein aggregates by disaggregation machines. Mol Cell 69: 214-226. doi:10.1016/j.molcel.2018.01.004

Mok SA, Condello C, Freilich R, Gillies A, Arhar T, Oroz J, Kadavath H, Julien O, Assimon VA, Rauch JN, et al. 2018. Mapping interactions with the chaperone network reveals factors that protect against tau aggregation. Nat Struct Mol Biol 25: 384-393. doi:10.1038/s41594-018-0057-1

Monsellier E, Redeker V, Ruiz-Arlandis G, Bousset L, Melki R. 2015. Molecular Interaction between the chaperone Hsc70 and the N-terminal flank of Huntingtin exon 1 modulates aggregation. J Biol Chem 290: 2560-2576. doi:10.1074/jbc.M114.603332
* Morimoto RI. 2018. Cell non-autonomous regulation of proteostasis in aging and disease. Cold Spring Harb Perspect Biol doi:10.1101/cshperspect.a034074

Morris AM, Watzky MA, Finke RG. 2009. Protein aggregation kinetics, mechanism, and curve-fitting: A review of the literature. Biochim Biophys Acta 1794: 375-397. doi:10.1016/j.bbapap.2008.10.016

Muchowski PJ, Schaffar G, Sittler A, Wanker EE, HayerHartl MK, Hartl FU. 2000. Hsp70 and hsp40 chaperones can inhibit self-assembly of polyglutamine proteins into amyloid-like fibrils. Proc Natl Acad Sci 97: 7841-7846. doi:10.1073/pnas.140202897

Narayan P, Orte A, Clarke RW, Bolognesi B, Hook S, Ganzinger KA, Meehan S, Wilson MR, Dobson CM, Klenerman D. 2012. The extracellular chaperone clusterin sequesters oligomeric forms of the amyloid- $\beta(1-40)$ peptide. Nat Struct Mol Biol 19: 79-83. doi:10.1038/ nsmb.2191

Neudecker P, Robustelli P, Cavalli A, Walsh P, Lundstrom P, Zarrine-Afsar A, Sharpe S, Vendruscolo M, Kay LE. 2012 Structure of an intermediate state in protein folding and aggregation. Science 336: 362-366. doi:10.1126/science. 1214203

Ngolab J, Trinh I, Rockenstein E, Mante M, Florio J, Trejo M, Masliah D, Adame A, Masliah E, Rissman RA. 2017. Brain-derived exosomes from dementia with Lewy bodies propagate $\alpha$-synuclein pathology. Acta Neuropathol Commun 5: 46. doi:10.1186/s40478-017-0445-5

Nillegoda NB, Kirstein J, Szlachcic A, Berynskyy M, Stank A, Stengel F, Arnsburg K, Gao X, Scior A, Aebersold R, et al 2015. Crucial HSP70 co-chaperone complex unlocks metazoan protein disaggregation. Nature 524: 247-251. doi:10.1038/nature14884

Nillegoda NB, Wentink AS, Bukau B. 2018. Protein disaggregation in multicellular organisms. Trends Biochem Sci 43: 285-300. doi:10.1016/j.tibs.2018.02.003

Oh SH, Kim HN, Park HJ, Shin JY, Bae EJ, Sunwoo MK, Lee SJ, Lee PH. 2016. Mesenchymal stem cells inhibit transmission of $\alpha$-synuclein by modulating clathrin-mediated endocytosis in a parkinsonian model. Cell Rep 14: 835849. doi:10.1016/j.celrep.2015.12.075

Ojha J, Masilamoni G, Dunlap D, Udoff RA, Cashikar AG. 2011. Sequestration of toxic oligomers by $\mathrm{HspB} 1$ as a cytoprotective mechanism. Mol Cell Biol 31: 3146-3157. doi:10.1128/MCB.01187-10

Olzscha H, Schermann SM, Woerner AC, Pinkert S, Hecht MH, Tartaglia GG, Vendruscolo M, Hayer-Hartl M, Hartl FU, Vabulas RM. 2011. Amyloid-like aggregates sequester numerous metastable proteins with essential cellular functions. Cell 144: 67-78. doi:10.1016/j.cell.2010.11.050

Oskarsson ME, Hermansson E, Wang Y, Welsh N, Presto J, Johansson J, Westermark GT. 2018. BRICHOS domain of Bri2 inhibits islet amyloid polypeptide (IAPP) fibril formation and toxicity in human $\beta$ cells. Proc Natl Acad Sci 115: E2752-E2761. doi:10.1073/pnas.1715951115

* Otzen D, Riek R. 2018. Functional amyloids. Cold Spring Harb Perspect Biol doi: 10.1101/cshperspect.a033860

Oueslati A, Fournier M, Lashuel HA. 2010. Role of posttranslational modifications in modulating the structure, function and toxicity of $\alpha$-synuclein: implications for Parkinson's disease pathogenesis and therapies. Prog Brain Res 183: 115-145. doi:10.1016/S0079-6123(10)83007-9 
Paravastu AK, Leapman RD, Yau WM, Tycko R. 2008. Molecular structural basis for polymorphism in Alzheimer's $\beta$-amyloid fibrils. Proc Natl Acad Sci 105: 18349-18354. doi:10.1073/pnas.0806270105

Paris D, Ganey NJ, Laporte V, Patel NS, Beaulieu-Abdelahad D, Bachmeier C, March A, Ait-Ghezala G, Mullan MJ 2010 . Reduction of $\beta$-amyloid pathology by celastrol in a transgenic mouse model of Alzheimer's disease. J Neuroinflammation 7: 17. doi:10.1186/1742-2094-7-17

Park SH, Kukushkin Y, Gupta R, Chen T, Konagai A, Hipp MS, Hayer-Hartl M, Hartl FU. 2013. PolyQ proteins interfere with nuclear degradation of cytosolic proteins by sequestering the Sislp chaperone. Cell 154: 134-145. doi:10.1016/j.cell.2013.06.003

Pavel M, Imarisio S, Menzies FM, Jimenez-Sanchez M, Siddiqi FH, Wu X, Renna M, O'Kane CJ, Crowther DC, Rubinsztein DC. 2016. CCT complex restricts neuropathogenic protein aggregation via autophagy. Nat Commun 7: 13821. doi:10.1038/ncomms13821

Peinado JR, Sami F, Rajpurohit N, Lindberg I. 2013. Blockade of islet amyloid polypeptide fibrillation and cytotoxicity by the secretory chaperones 7B2 and proSAAS. FEBS Lett 587: 3406-3411. doi:10.1016/j.febslet.2013.09.006

Pemberton S, Madiona K, Pieri L, Kabani M, Bousset L, Melki R. 2011. Hsc70 protein interaction with soluble and fibrillar $\alpha$-synuclein. J Biol Chem 286: 3469034699. doi:10.1074/jbc.M111.261321

Pierce A, Podlutskaya N, Halloran JJ, Hussong SA, Lin PY, Burbank R, Hart MJ, Galvan V. 2013. Over-expression of heat shock factor 1 phenocopies the effect of chronic inhibition of TOR by rapamycin and is sufficient to ameliorate Alzheimer's-like deficits in mice modeling the disease. J Neurochem 124: 880-893. doi:10.1111/jnc.12080

Poska H, Haslbeck M, Kurudenkandy FR, Hermansson E Chen G, Kostallas G, Abelein A, Biverstal H, Crux S, Fisahn A, et al. 2016. Dementia-related Bri2 BRICHOS is a versatile molecular chaperone that efficiently inhibits Aß42 toxicity in Drosophila. Biochem J 473: 3683-3704. doi:10.1042/BCJ20160277

Prabhu S, Raman B, Ramakrishna T, Rao CM. 2012. HspB2/ myotonic dystrophy protein kinase binding protein (MKBP) as a novel molecular chaperone: structural and functional aspects. PLoS ONE 7: e29810. doi:10.1371/ journal.pone.0029810

Prusiner SB. 1998. Prions. Proc Natl Acad Sci 95: 1336313383. doi:10.1073/pnas.95.23.13363

Quintas A, Vaz DC, Cardoso I, Saraiva MJ, Brito RM. 2001. Tetramer dissociation and monomer partial unfolding precedes protofibril formation in amyloidogenic transthyretin variants. J Biol Chem 276: 27207-27213. doi:10.1074/jbc.M101024200

Quist A, Doudevski I, Lin H, Azimova R, Ng D, Frangione B, Kagan B, Ghiso J, Lal R. 2005. Amyloid ion channels: A common structural link for protein-misfolding disease. Proc Natl Acad Sci 102: 10427-10432. doi:10.1073/ pnas.0502066102

Raman B, Ban T, Sakai M, Pasta SY, Ramakrishna T, Naiki H, Goto Y, Rao Ch M. 2005. $\alpha$ B-crystallin, a small heat-shock protein, prevents the amyloid fibril growth of an amyloid $\beta$-peptide and $\beta_{2}$-microglobulin. Biochem J 392: 573-581. doi:10.1042/BJ20050339
Ries HM, Nussbaum-Krammer C. 2016. Shape matters: The complex relationship between aggregation and toxicity in protein-misfolding diseases. Essays Biochem 60: 181-190. doi:10.1042/EBC20160008

Rosas PC, Nagaraja GM, Kaur P, Panossian A, Wickman G, Garcia LR, Al-Khamis FA, Asea AA. 2016. hsp72 (hspala) prevents human islet amyloid polypeptide aggregation and toxicity: A new approach for type 2 diabetes treatment. PLoS ONE 11: e0149409. doi:10.1371/journal. pone.0149409

Rudiger S, Germeroth L, Schneider-Mergener J, Bukau B. 1997. Substrate specificity of the DnaK chaperone determined by screening cellulose-bound peptide libraries. EMBO J 16: 1501-1507. doi:10.1093/emboj/16.7.1501

Rudiger S, Schneider-Mergener J, Bukau B. 2001. Its substrate specificity characterizes the DnaJ co-chaperone as a scanning factor for the DnaK chaperone. EMBO J 20: 1042-1050. doi:10.1093/emboj/20.5.1042

Sahu R, Kaushik S, Clement CC, Cannizzo ES, Scharf B, Follenzi A, Potolicchio I, Nieves E, Cuervo AM, Santambrogio L. 2011. Microautophagy of cytosolic proteins by late endosomes. Dev Cell 20: 131-139. doi:10.1016/j. devcel.2010.12.003

Saibil H. 2013. Chaperone machines for protein folding, unfolding and disaggregation. Nat Rev Mol Cell Biol 14: 630-642. doi:10.1038/nrm3658

Sakono M, Zako T, Ueda H, Yohda M, Maeda M. 2008. Formation of highly toxic soluble amyloid $\beta$ oligomers by the molecular chaperone prefoldin. FEBS $J$ 275: 5982-5993. doi:10.1111/j.1742-4658.2008.06727.x

Schirmer C, Lepvrier E, Duchesne L, Decaux O, Thomas D, Delamarche C, Garnier C. 2016. Hsp90 directly interacts, in vitro, with amyloid structures and modulates their assembly and disassembly. Biochim Biophys Acta 1860: 2598-2609. doi:10.1016/j.bbagen.2016.07.033

Scior A, Buntru A, Arnsburg K, Ast A, Iburg M, Juenemann K, Pigazzini ML, Mlody B, Puchkov D, Priller J, et al. 2018. Complete suppression of Htt fibrilization and disaggregation of Htt fibrils by a trimeric chaperone complex. EMBO J 37: 282-299. doi:10.15252/embj.201797212

Serio TR, Cashikar AG, Kowal AS, Sawicki GJ, Moslehi JJ, Serpell L, Arnsdorf MF, Lindquist SL. 2000. Nucleated conformational conversion and the replication of conformational information by a prion determinant. Science 289: 1317-1321. doi:10.1126/science.289.5483.1317

Shahmoradian SH, Galaz-Montoya JG, Schmid MF, Cong Y, Ma B, Spiess C, Frydman J, Ludtke SJ, Chiu W. 2013. TRiC's tricks inhibit huntingtin aggregation. eLife 2: e00710. doi:10.7554/eLife.00710

Shammas SL, Waudby CA, Wang S, Buell AK, Knowles TP, Ecroyd H, Welland ME, Carver JA, Dobson CM, Meehan S. 2011. Binding of the molecular chaperone $\alpha \mathrm{B}$-crystallin to $A \beta$ amyloid fibrils inhibits fibril elongation. Biophys $J$ 101: 1681-1689. doi:10.1016/j.bpj.2011.07.056

Sharma M, Burre J, Bronk P, Zhang Y, Xu W, Sudhof TC. 2012. CSP $\alpha$ knockout causes neurodegeneration by impairing SNAP-25 function. EMBO J 31: 829-841. doi:10.1038/emboj.2011.467

Shelton LB, Baker JD, Zheng D, Sullivan LE, Solanki PK, Webster JM, Sun Z, Sabbagh JJ, Nordhues BA, Koren J III, et al. 2017. Hsp90 activator Aha1 drives production of 
A. Wentink et al.

pathological tau aggregates. Proc Natl Acad Sci 114: 9707 9712. doi:10.1073/pnas.1707039114

Shi A, Sun L, Banerjee R, Tobin M, Zhang Y, Grant BD. 2009 Regulation of endosomal clathrin and retromer-mediated endosome to Golgi retrograde transport by the J-domain protein RME-8. EMBO J 28: 3290-3302. doi:10.1038/emboj.2009.272

* Shorter J, Southworth DR. 2018. Spiraling in control: Structures and mechanisms of the Hsp104 disaggregase. Cold Spring Harb Perspect Biol doi:10.1101/cshperspect. a034033

Soderberg CAG, Mansson C, Bernfur K, Rutsdottir G, Harmark J, Rajan S, Al-Karadaghi S, Rasmussen M, Hojrup P, Hebert H, et al. 2018. Structural modelling of the DNAJB6 oligomeric chaperone shows a peptide-binding cleft lined with conserved S/T-residues at the dimer interface. Sci Rep 8: 5199.

Sorgjerd K, Ghafouri B, Jonsson BH, Kelly JW, Blond SY, Hammarstrom P. 2006. Retention of misfolded mutant transthyretin by the chaperone BiP/GRP78 mitigates amyloidogenesis. J Mol Biol 356: 469-482. doi:10.1016/ j.jmb.2005.11.051

Sot B, Rubio-Muñoz A, Leal-Quintero A, Martínez-Sabando J, Marcilla M, Roodveldt C, Valpuesta JM. 2017. The chaperonin CCT inhibits assembly of $\alpha$-synuclein amyloid fibrils by a specific, conformation-dependent interaction. Sci Rep 7: 40859. doi:10.1038/srep40859

Soto C. 2003. Unfolding the role of protein misfolding in neurodegenerative diseases. Nat Rev Neurosci 4: 49-60. doi:10.1038/nrn1007

Sousa R, Lafer EM. 2015. The role of molecular chaperones in clathrin mediated vesicular trafficking. Front Mol Biosci 2: 26. doi:10.3389/fmolb.2015.00026

Specht S, Miller SBM, Mogk A, Bukau B. 2011. Hsp42 is required for sequestration of protein aggregates into deposition sites in Saccharomyces cerevisiae. J Cell Biol 195: 617-629. doi:10.1083/jcb.201106037

Stroo E, Koopman M, Nollen EA, Mata-Cabana A. 2017. Cellular regulation of amyloid formation in aging and disease. Front Neurosci 11: 64. doi:10.3389/fnins. 2017.00064

Sun CS, Lee CC, Li YN, Yao-Chen Yang S, Lin CH, Chang YC, Liu PF, He RY, Wang CH, Chen W, et al. 2015. Conformational switch of polyglutamine-expanded huntingtin into benign aggregates leads to neuroprotective effect. Sci Rep 5: 14992. doi:10.1038/srep14992

Tam S, Geller R, Spiess C, Frydman J. 2006. The chaperonin TRiC controls polyglutamine aggregation and toxicity through subunit-specific interactions. Nat Cell Biol 8: 1155-1162. doi:10.1038/ncb1477

Tam S, Spiess C, Auyeung W, Joachimiak L, Chen B, Poirier MA, Frydman J. 2009. The chaperonin TRiC blocks a huntingtin sequence element that promotes the conformational switch to aggregation. Nat Struct Mol Biol 16: 1279-1285. doi:10.1038/nsmb.1700

Tanaka M, Collins SR, Toyama BH, Weissman JS. 2006. The physical basis of how prion conformations determine strain phenotypes. Nature 442: 585-589. doi:10.1038/nature 04922

Tashiro E, Zako T, Muto H, Itoo Y, Sorgjerd K, Terada N, Abe A, Miyazawa M, Kitamura A, Kitaura H, et al. 2013. Prefoldin protects neuronal cells from polyglutamine tox- icity by preventing aggregation formation. $J$ Biol Chem 288: 19958-19972. doi:10.1074/jbc.M113.477984

Tekirdag K, Cuervo AM. 2018. Chaperone-mediated autophagy and endosomal microautophagy: Jointed by a chaperone. J Biol Chem 293: 5414-5424. doi:10.1074/ jbc.R117.818237

Thibaudeau TA, Anderson RT, Smith DM. 2018. A common mechanism of proteasome impairment by neurodegenerative disease-associated oligomers. Nat Commun 9: 1097. doi:10.1038/s41467-018-03509-0

Thompson AD, Scaglione KM, Prensner J, Gillies AT, Chinnaiyan A, Paulson HL, Jinwal UK, Dickey CA, Gestwicki JE. 2012. Analysis of the tau-associated proteome reveals that exchange of Hsp70 for Hsp90 is involved in tau degradation. ACS Chem Biol 7: 1677-1686. doi:10.1021/ cb3002599

Tipping KW, Karamanos TK, Jakhria T, Iadanza MG, Goodchild SC, Tuma R, Ranson NA, Hewitt EW, Radford SE. 2015. $\mathrm{pH}$-induced molecular shedding drives the formation of amyloid fibril-derived oligomers. Proc Natl Acad Sci 112: 5691-5696. doi:10.1073/pnas.1423174112

Tuttle MD, Comellas G, Nieuwkoop AJ, Covell DJ, Berthold DA, Kloepper KD, Courtney JM, Kim JK, Barclay AM, Kendall A, et al. 2016. Solid-state NMR structure of a pathogenic fibril of full-length human $\alpha$-synuclein. Nat Struct Mol Biol 23: 409-415. doi:10.1038/nsmb.3194

Tyedmers J, Mogk A, Bukau B. 2010. Cellular strategies for controlling protein aggregation. Nat Rev Mol Cell Biol 11: 777-788. doi:10.1038/nrm2993

Ungelenk S, Moayed F, Ho CT, Grousl T, Scharf A, Mashaghi A, Tans S, Mayer MP, Mogk A, Bukau B. 2016. Small heat shock proteins sequester misfolding proteins in nearnative conformation for cellular protection and efficient refolding. Nat Commun 7: 13673. doi:10.1038/ ncomms 13673

Valera E, Masliah E. 2016. Therapeutic approaches in Parkinson's disease and related disorders. J Neurochem 139 (Suppl 1): 346-352. doi:10.1111/jnc.13529

Victoria GS, Zurzolo C. 2017. The spread of prion-like proteins by lysosomes and tunneling nanotubes: Implications for neurodegenerative diseases. J Cell Biol 216: 2633-2644.

Vilar M, Chou HT, Luhrs T, Maji SK, Riek-Loher D, Verel R, Manning G, Stahlberg H, Riek R. 2008. The fold of $\alpha$ synuclein fibrils. Proc Natl Acad Sci 105: 8637-8642. doi:10.1073/pnas.0712179105

Voss K, Combs B, Patterson KR, Binder LI, Gamblin TC. 2012. Hsp70 alters tau function and aggregation in an isoform specific manner. Biochemistry 51: 888-898. doi: 10.1021/bi2018078

Wacker JL, Zareie MH, Fong H, Sarikaya M, Muchowski PJ. 2004. Hsp70 and Hsp40 attenuate formation of spherical and annular polyglutamine oligomers by partitioning monomer. Nat Struct Mol Biol 11: 1215-1222. doi: $10.1038 / \mathrm{nsmb} 860$

Walther DM, Kasturi P, Zheng M, Pinkert S, Vecchi G, Ciryam P, Morimoto RI, Dobson CM, Vendruscolo M, Mann M, et al. 2015. Widespread proteome remodeling and aggregation in aging C. elegans. Cell 161: 919-932. doi:10.1016/j.cell.2015.03.032

Wang JZ, Xia YY, Grundke-Iqbal I, Iqbal K. 2013. Abnormal hyperphosphorylation of tau: Sites, regulation, and mo- 
lecular mechanism of neurofibrillary degeneration. $J \mathrm{Alz}$ heimers Dis 33 (Suppl 1): S123-139.

Waudby CA, Knowles TP, Devlin GL, Skepper JN, Ecroyd H, Carver JA, Welland ME, Christodoulou J, Dobson CM, Meehan S. 2010. The interaction of $\alpha B$-crystallin with mature $\alpha$-synuclein amyloid fibrils inhibits their elongation. Biophys J 98: 843-851. doi:10.1016/j.bpj. 2009. 10.056

Whiten DR, Cox D, Horrocks MH, Taylor CG, De S, Flagmeier P, Tosatto L, Kumita JR, Ecroyd H, Dobson CM, et al. 2018. Single-molecule characterization of the interactions between extracellular chaperones and toxic $\alpha$-synuclein oligomers. Cell Rep 23: 3492-3500. doi:10.1016/j. celrep.2018.05.074

Wilhelmus MM, Boelens WC, Otte-Höller I, Kamps B, de Waal RM, Verbeek MM. 2006a. Small heat shock proteins inhibit amyloid- $\beta$ protein aggregation and cerebrovascular amyloid- $\beta$ protein toxicity. Brain Res 1089: 67-78. doi:10.1016/j.brainres.2006.03.058

Wilhelmus MM, Boelens WC, Otte-Höller I, Kamps B, Kusters B, Maat-Schieman ML, de Waal RM, Verbeek MM. 2006b. Small heat shock protein HspB8: its distribution in Alzheimer's disease brains and its inhibition of amyloid- $\beta$ protein aggregation and cerebrovascular amyloid- $\beta$ toxicity. Acta Neuropathol 111: 139-149. doi:10.1007/ s00401-005-0030-z

Willander H, Presto J, Askarieh G, Biverstål H, Frohm B, Knight SD, Johansson J, Linse S. 2012. BRICHOS domains efficiently delay fibrillation of amyloid $\beta$-peptide. $J$ Biol Chem 287: 31608-31617. doi:10.1074/jbc. M112.393157

Xu X, Sarbeng EB, Vorvis C, Kumar DP, Zhou L, Liu Q. 2012 Unique peptide substrate binding properties of $110-\mathrm{kDa}$ heat-shock protein (Hsp110) determine its distinct chap- erone activity. J Biol Chem 287: 5661-5672. doi:10.1074/ jbc.M111.275057

Xu Z, Graham K, Foote M, Liang F, Rizkallah R, Hurt M, Wang Y, Wu Y, Zhou Y. 2013. 14-3-3 protein targets misfolded chaperone-associated proteins to aggresomes. J Cell Sci 126: 4173-4186. doi:10.1242/jcs. 126102

Xu Y, Cui L, Dibello A, Wang L, Lee J, Saidi L, Lee JG, Ye Y. 2018. DNAJC5 facilitates USP19-dependent unconventional secretion of misfolded cytosolic proteins. Cell Discov 4: 11. doi:10.1038/s41421-018-0012-7

Yerbury JJ, Poon S, Meehan S, Thompson B, Kumita JR, Dobson CM, Wilson MR. 2007. The extracellular chaperone clusterin influences amyloid formation and toxicity by interacting with prefibrillar structures. FASEB $J \mathbf{2 1}$ : 2312-2322. doi:10.1096/fj.06-7986com

Yerbury JJ, Kumita JR, Meehan S, Dobson CM, Wilson MR. 2009. $\alpha_{2}$-Macroglobulin and haptoglobin suppress amyloid formation by interacting with prefibrillar protein species. J Biol Chem 284: 4246-4254. doi:10.1074/jbc. M807242200

Young ZT, Mok SA, Gestwicki JE. 2018. Therapeutic strategies for restoring tau homeostasis. Cold Spring Harb Perspect Med 8: a024612. doi:10.1101/cshperspect.a024612

Yu JT, Tan L. 2012. The role of clusterin in Alzheimer's disease: pathways, pathogenesis, and therapy. Mol Neurobiol 45: 314-326. doi:10.1007/s12035-012-8237-1

Yu A, Shibata Y, Shah B, Calamini B, Lo DC, Morimoto RI. 2014. Protein aggregation can inhibit clathrin-mediated endocytosis by chaperone competition. Proc Natl Acad Sci 111: E1481-E1490. doi:10.1073/pnas.1321811111

Zhang Y, Grant B, Hirsh D. 2001. RME-8, a conserved Jdomain protein, is required for endocytosis in Caenorhabditis elegans. Mol Biol Cell 12: 2011-2021. doi: 10.1091/mbc.12.7.2011 


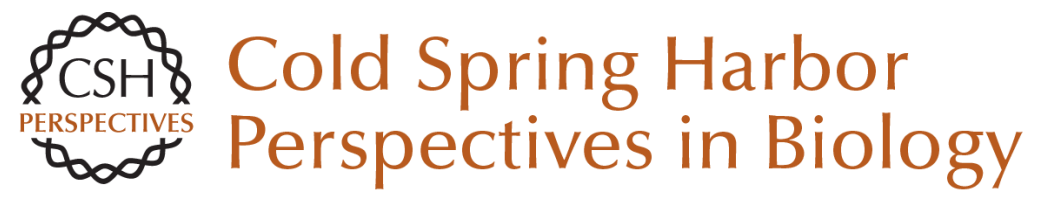

\section{Modulation of Amyloid States by Molecular Chaperones}

Anne Wentink, Carmen Nussbaum-Krammer and Bernd Bukau

Cold Spring Harb Perspect Biol 2019; doi: 10.1101/cshperspect.a033969 originally published online February 12, 2019

\section{Subject Collection Protein Homeostasis}

Proteome-Scale Mapping of Perturbed

Proteostasis in Living Cells

Isabel Lam, Erinc Hallacli and Vikram Khurana

Pharmacologic Approaches for Adapting Proteostasis in the Secretory Pathway to

Ameliorate Protein Conformational Diseases Jeffery W. Kelly

Cell-Nonautonomous Regulation of Proteostasis in Aging and Disease

Richard I. Morimoto

The Autophagy Lysosomal Pathway and

Neurodegeneration

Steven Finkbeiner

Functional Modules of the Proteostasis Network Gopal G. Jayaraj, Mark S. Hipp and F. Ulrich Hartl

Protein Solubility Predictions Using the CamSol Method in the Study of Protein Homeostasis Pietro Sormanni and Michele Vendruscolo

Recognition and Degradation of Mislocalized

Proteins in Health and Disease

Ramanujan S. Hegde and Eszter Zavodszky

The Nuclear and DNA-Associated Molecular Chaperone Network

Zlata Gvozdenov, Janhavi Kolhe and Brian C. Freeman
The Amyloid Phenomenon and Its Significance in Biology and Medicine

Christopher M. Dobson, Tuomas P.J. Knowles and Michele Vendruscolo

A Chemical Biology Approach to the Chaperome

in Cancer--HSP9O and Beyond

Tony Taldone, Tai Wang, Anna Rodina, et al.

Proteostasis in Viral Infection: Unfolding the Complex Virus-Chaperone Interplay Ranen Aviner and Judith Frydman

The Proteasome and Its Network: Engineering for Adaptability Daniel Finley and Miguel A. Prado

Functional Amyloids Daniel Otzen and Roland Riek

Chaperone Interactions at the Ribosome Elke Deuerling, Martin Gamerdinger and Stefan G. Kreft

Mechanisms of Small Heat Shock Proteins Maria K. Janowska, Hannah E.R. Baughman, Christopher N. Woods, et al.

Structure, Function, and Regulation of the Hsp90 Machinery

Maximilian M. Biebl and Johannes Buchner

For additional articles in this collection, see http://cshperspectives.cshlp.org/cgi/collection/

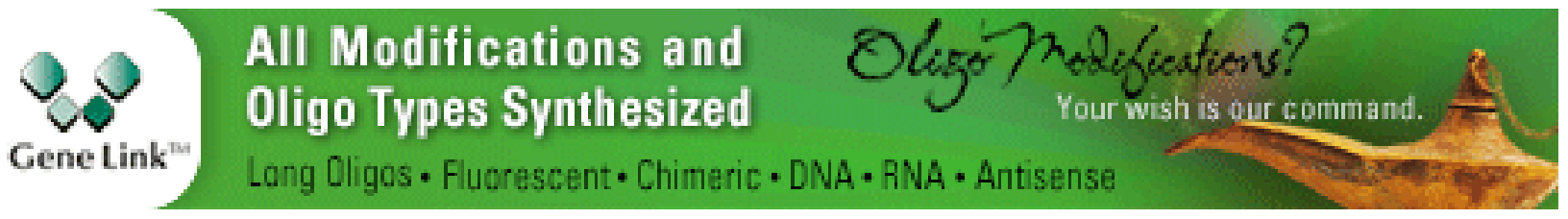


For additional articles in this collection, see http://cshperspectives.cshlp.org/cgi/collection/

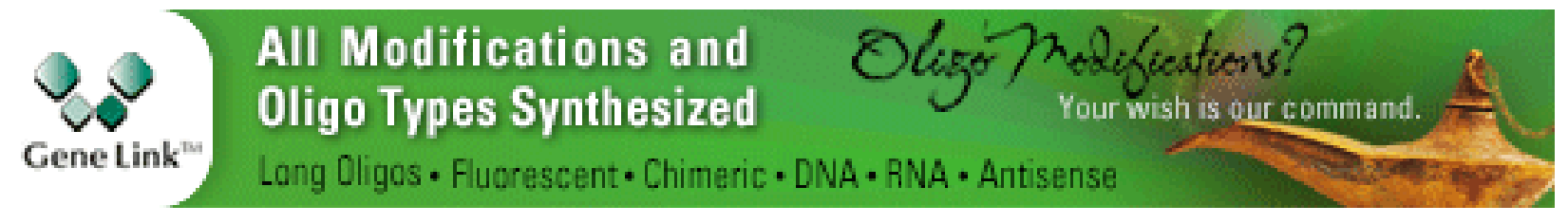

Copyright @ 2019 Cold Spring Harbor Laboratory Press; all rights reserved 